\title{
A BIBLOGRAPHIC CLAVIS TO THE WORKS OF PHILOXENOS OF MABBUG
}

\author{
DAVID A. MiCHELSON
}

UNIVERSITY OF ALABAMA

\begin{abstract}
Philoxenos of Mabbug was one of the more prolific Syriac authors of late antiquity. Since 1963 the carefully researched monograph of André de Halleux, Philoxène de Mabbog: Sa vie, ses écrits, sa théologie, has served as a handbook to the works of this key figure in the history of the West Syrian tradition. De Halleux's work has been so productive in opening up the riches of Pbiloxenos for study in a variety of fields (bistory, theology, New Testament studies, and the study of Syriac literature) that now, nearly balf a century later, there is a need for a revised clavis to make accessible the new editions, translations, and secondary literature. This clavis is a simple supplement to the work of de Halleux.
\end{abstract}

\section{CONTENTS}

I. Preface 274

II. General Studies and Presentations

A. Sections in introductory works and handbooks related to Syriac studies

B. Articles in dictionaries and encyclopedias 281

C. Mention in bibliographic reference works 285 


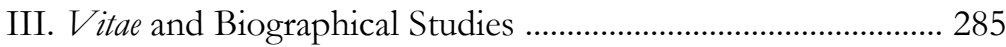

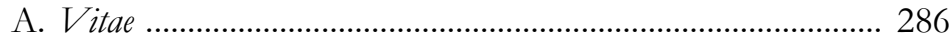

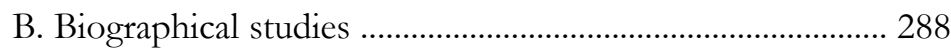

IV. Survey of the Works Attributed to Philoxenos ....................... 288

A. Extant works and fragments .............................................. 289

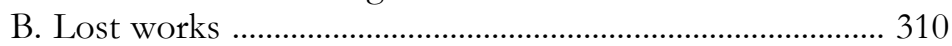

C. Dubious and spurious works .............................................. 312

V. Studies and Mention in Selected General Works .................... 321

A. Monographs with extended treatment of Philoxenos ..... 321

B. Monographs with mention of Philoxenos ......................... 322

C. Unpublished dissertations and theses ................................. 325

D. Articles and chapters in collected volumes with extended treatment of Philoxenos ........................... 326

E. Articles and chapters in collected volumes with mention of Philoxenos

\section{PREFACE}

Philoxenos of Mabbug (d. 523) was a driven figure living in a time of ecclesiastical volatility. Over his lifetime he successfully played several different leadership roles within the churches of lateantique Syria including those of bishop, ascetic guide, theologian, exegete, patron of biblical scholarship, polemicist, and even wouldbe imperial counselor. In these various roles he wrote prolifically, leaving works in a wide range of genres including polemics, Biblical commentary, homilies, doctrinal theology, letters, and ascetic paranaesis.

As the Christological controversies permanently separated the Western churches from the Syriac churches, knowledge of Philoxenos or his works faded in West. If he was mentioned at all, he usually suffered condemnation in the same breath as anathemas of his "monophysite" Christology. Beginning in the nineteenth century, however, western scholars began to rediscover and publish his works (one of which had actually continued to circulate in Greek during the middle ages under the name of Isaac of Nineveh-see no. 44 below). In the first half of the twentieth century, western interest in Philoxenos flourished due to two factors. First, J. Lebon's sympathetic and nuanced study of the onenature Christology of Philoxenos and Severus opened the way for scholars to move beyond the narrow and caricatured categories 
which the Christological controversies had left in their wake. At the same time, the work of I. Hausherr and his students made the contemplative systems of eastern Christian asceticism accessible to western theologians. As one of the most prominent voices in the West Syrian tradition for both one-nature Christology and Evagrian asceticism, Philoxenos began to enjoy increased scholarly attention.

In 1963, Philoxenos was the subject of a careful and detailed study by A. de Halleux. ${ }^{1}$ Building on the work of E.A.W. Budge, Lebon, and others, de Halleux offered a comprehensive guide to the works of Philoxenos on several levels ranging from codicology to Christology. De Halleux's work remains today the starting point for all work on Philoxenos. At the time of its publication, however, only a little over half of the works of Philoxenos were published and the secondary literature dedicated to Philoxenos was limited (apart from textual work on the Philoxenian New Testament which had been active since the eighteenth century but was only secondarily interested in Philoxenos). In 1963 de Halleux was able to present the bibliography for his nearly six-hundred-page study in just over twenty pages. As a guide to Philoxenos since that time, de Halleux's work has been enormously successful and has opened the flood gates to the study and publishing of Philoxenian works. After nearly half a century, however, a supplement to de Halleux is needed, if only to guide students and scholars to find new editions and translations of Philoxenos' considerable corpus.

In preparing this clavis I have made use of the excellent models previously published by Dirk Kruisheer, Lucas Van Rompay, and Edward Mathews, Jr. in Hugoye. ${ }^{2}$ I have generally followed their format with regards to structuring the clavis and to citation style. I have also followed their precedent with regard to scope, opting not to survey manuscript catalogues or present manuscript evidence in detail. Like these authors, I have also relied on the bibliographies of Moss, Brock, and now Pinggéra and Kessel. While I have personally inspected nearly all of the items in

1 A. de Halleux, Philoxène de Mabbog: Sa vie, ses écrits, sa théologie (Louvain 1963).

${ }^{2}$ D. Kruisheer and L. Van Rompay, "A Bibliographic Clavis to the Works of Jacob of Edessa," Hugoye 1.1 (1998) and Edward Mathews, Jr., "A Bibliographic Clavis to the Corpus of Works attributed to Isaac of Antioch," Hugoye 5.1 (2002). 
this bibliography, I have relied on these bibliographies for a few items I was not able to access. In the cases of such items, I have only marked items as "non vidi" when the item was sufficiently rare as to leave the citation uncertain.

In addition to the work of these aforementioned bibliographers, the greatest debt of this present clavis is to the work of de Halleux. This clavis is meant to supplement, not replace, de Halleux's monograph. I have purposely keyed my list of Philoxenos' works to mirror their order of presentation in De Halleux so that this clavis can be easily consulted in conjunction with the work of de Halleux. Moreover, while this clavis is the result of a few years of collecting bibliography, I have not intended it to exhaustively answer all Philoxenian-related questions. ${ }^{3}$ More modestly, this bibliography is designed to bring the reader up-to-date with regard to the scholarly questions first posed by de Halleux (primarily questions of ascesis, christology, and history).

Indeed, I would like to make an appeal to the scholarly community by pointing out that in the areas of Philoxenian scholarship where de Halleux's monograph did not lay particularly detailed groundwork further preliminary research needs to be done before we can have a comprehensive clavis. For example, at the time of writing de Halleux was not able to consult many middle eastern manuscript collections and thus the question of what Philoxenian works remain to be re-discovered is still wide open. Or, as another example, due to the aims of his work de Halleux did not devote much attention to cataloging and tracing the numerous liturgical traditions which were later attached to Philoxenos' name; this field remains another fruitful area for future research. There is enough here to occupy more than one scholar. We could use detailed studies on Philoxenos' interaction with his contemporaries (especially Severus), on Philoxenos' legacy in the other literatures of eastern Christianity (particularly in Armenian and Arabic literature), and on Philoxenos' reception-history within the

${ }^{3}$ For this reason, I have generally not included book reviews in the clavis except in the case of reviews making important interventions. Further monographs reviews can be located through the articles in encyclopedias and dictionaries listed in section II. B. See particularly the list in E. Kettenhofen's "Philoxenos" in Biographisch-Bibliographisches Kirchenlexicon, vol. VII (Herzberg 1994), 542-549. 
intellectual and devotional life of the Syrian Orthodox Church. ${ }^{4}$ Accordingly these topics can only be treated in a preliminary way in the present clavis. Most importantly, readers are referred to de Halleux for detailed lists of manuscripts containing Philoxenian works. Below, I have only indicated the manuscripts of primary importance as an aide to the reader in navigating the literature or locating unpublished works. A complete manuscript tree of the Philoxenian corpus taking into account collections catalogued since de Halleux remains to be another major project which I hope to undertake at a later date (and for which I would invite readers to send me citations to correllate with the present clavis).

On a related note, I also alert the reader that this clavis has not attempted to be exhaustive with regards to the question of the Philoxenian New Testament. This decision is not due to lack of literature, but because the scope and aims of the text critical scholarship on the Philoxenian are distinct enough to merit their own treatment by scholars competent in Biblical studies. I have, nevertheless, included most of the relevant recent bibliography on the Philoxenian in the hopes that it will be useful for a Biblical scholar to prepare an addendum on the Philoxenian Biblical version. In fact, such is my aim in general for this clavis, that it would serve as a modest but useful supplement to de Halleux and in some small way follow his example and encourage further scholarship on the extensive corpus of Philoxenos.

The prospects for future scholarship are quite bright. In addition to the increasing number of monographs, dissertations, and articles appearing on Philoxenos, his works are becoming accessible in greater numbers and new formats. For example,

${ }^{4}$ Some recent work is being done on these questions as documented below, but there is room for more. Specifically, see the work of Roger Akhrass on compiling a new complete corpus of Philoxenos including middle eastern MSS and liturgica; the work of Iuliana Viezure on the role of Philoxenos in the theopaschite controversies; the work of S. Peter Cowe and Karl Pingèrra on the legacy of Philoxenos in Armenia; the article in this current issue of Hugoye by Adam McCollum on the reception of Philoxenos in Arabic, and the work of Dan King and my own work on the place of Philoxenos in the later developments in Syriac thought and theology. Another particularly interesting question would be how the later anti-Julianist controversy affected the reception of Philoxenos. 
Robert Kitchen is nearing completion of a new English translation of the "Discourses" which will ensure that the largest and mostwell-known Philoxenian work will continue to be accessible to students, scholars, and the general public alike. Similarly, Roger Akhrass has undertaken to make a popular-level modern Arabic translation of nearly all of the works of Philoxenos. ${ }^{5}$ Akhrass' work also includes re-editing the Syriac texts thus creating a unified corpus in Syriac. Kristian Heal, Akhrass, and I are now working to incorporate this corpus of over 500,000 words into the larger Syriac digital corpus project at Brigham Young University with the end result of creating an online searchable corpus of the works of Philoxenos. In a similar vein, I am pleased to let readers know that I plan to expand and update a version of the present clavis online to include Syriac incipits for the texts and more detailed manuscript schemata. I have written this clavis to serve as the model entry for a larger online clavis for all Syriac authors which will be curated by Beth Mardutho and hosted by several university partners. The proposed online clavis, The Syriac Reference Portal, will have an advantage over the present clavis in that it can be perpetually updated. To succeed in producing work similar to the three published in Hugoye so far (i.e. for Jacob of Edessa, Isaac of Antioch, and now Philoxenos), such an online clavis will need a large number of contributors and collaborators. Accordingly, I use the publication of this clavis as an opportunity to invite all scholars who might be interested in producing a clavis to consider joining this initiative. For interested scholars and institutional partners a preliminary description is available through the University of Alabama's Syriac Research Group homepage (www.syriac.ua.edu). ${ }^{6}$

Such are the prospects for future work on Philoxenos. At present we do not quite yet live in a world where research on Philoxenos is so accessible and so I would like to express my gratitude to a number of people who assisted me in the preparation of this clavis. First, my wife Bethany and my children put up with

5 See above. Three volumes have appeared with a fourth in preparation according to a communication with the author.

6 Preliminary information (as of November 2010) is available at www.syriac.ua.edu. Further information about this project will be presented in a workshop at the 2010 North American Syriac Symposium at Duke University and will also be made available on the web. 
Philoxenos' presence as a member of our family for which I am grateful beyond words. Bob Kitchen and George Kiraz both showed remarkable patience and provided assistance and encouragement as I put this together. Peter Brown also continued to reminder me of the value of studying Philoxenos. Sebastian Brock and Roger Akhrass both offered a number of helpful corrections. At various points Luk Van Rompay, David Taylor, Mary Hansbury, Karl Pinggéra, Gregory Kessel, Sergey Minov, Robin Darling Young, Jack Tannous, Dan Schwartz, Scott Johnson, Thomas Carlson, Iuliana Veizure, Dan King, Kutlu Akalin, Jon Loopstra, Adam McCollum, and especially James Walters all helped me with verifying citations or making me aware of an item. Moreover, my research assistants at Princeton University and the University of Alabama also put in time ferrying books and finding articles, especially Anna Megill, Chris Sherrill, Corbin Karl, Andrew Martin, and Robert Aydin. Similarly I also owe a whole shelf-load of thanks to the interlibrary loan staff at Gorgas Library at the University of Alabama. Lastly some of my colleagues helped me with languages or scripts beyond my reach, especially Dan Riches, Margaret Peacock and Ian Chapman. All mistakes and omissions, of course, remain my own.

Finally, I would like to conclude by making an appeal for readers to send me comments, especially with items I may have overlooked. I will incorporate these items and suggestions into the searchable online version I am preparing.

\section{General Studies AND Presentations}

\section{A. Sections in introductory works and handbooks related to Syriac studies}

J.S. Assemanus, Bibliotheca Orientalis Clementino-Vaticana II (Rome 1719) 10b-46a, et passim.

W. Wright, A Short History of Syriac Literature (London 1894) 72-76, et passim.

R. Duval, La littérature syriaque, $3^{\text {rd }}$ ed. (Paris 1907) 254-256, et passim.

C. Brockelmann, "Die syrische und die christlich-arabische Litteratur," in Gescbicbte der cbristlichen Litteraturen des Orients (Leipzig 1907), 27. 
A. Baumstark, Die christlichen Literaturen des Orients, I. Einleitung. I. Das christlich-aramäische und das koptische Scbrifttum (Leipzig 1911) 47, $56,70-75,89$.

A. Baumstark, Geschichte der syrischen Literatur (Bonn 1922) 141-144, et passim.

J.-B. Chabot, Littérature syriaque (Paris 1934) 64-66.

W.H.P. Hatch, An Album of Dated Syriac Manuscripts (Boston 1946) 59, 77, 83, see also $81,110,148,149,155,158$. [sample manuscript pages from Philoxenos' works]

A. Baumstark, "Aramäisch und Syrisch", in Semitistik, Handbuch der Orientalistik III. 1-3 (Leiden 1954), 183-184.

A.I. Barsoum, Kitaab al-h'lu' al-manthuur fii taariikh al'-uluum wa'l-aadaab alsuryaaniyya (Aleppo 1956; Glane-Losser 1987) [Eng. tr., in A.I. Barsoum, The Scattered Pearls: The History of Syriac Literature and Sciences, tr., Matti Mousa, $2^{\text {nd }}$ Rev. Ed. (Piscataway, N.J. 2003) 262-270].

I. Ortiz de Urbina, Patrologia Syriaca, $2^{\text {nd }}$ ed. (Rome 1965) 157-161.

J. Assfalg and P. Krüger, Kleines Wörterbuch des Christlichen Orients (Wiesbaden 1975), 297 et passim.

F. Winkelmann, Die östlichen Kirchen in der Epoche der christologischen Auseinandersetzung (5.-7. Jh.) (Berlin 1980), 53-54.

C. Detlef G. Müller, Geschicte der Orientalischen Nationalkirchen in Die Kirche in ibrer Geschicbte, Band 1, Lieferung D2 (Göttingen 1981), 280.

W.S. Mc Cullough, A Short History of Syriac Christianity to the Rise of Islam (Chicago 1982), 80-81.

C. Sélis, Les Syriens orthodoxes et catholiques (Brepols 1988), 44-53, 68-69, $111-114$.

P. Bettiolo, "Lineamenti di Patrologia Siriaca" in A. Quacquarelli (ed.), Complimenti interdisciplinari di Patrologia (Rome 1989), 552-557.

"Philoxenos of Mabboug," in S. Beggiani, Introduction to Eastern Christian Spirituality: The Syriac Tradition (Cranbury, N.J. 1991), 48-53.

L. Knezevich, "Philoxenos of Mabbug" in The Coptic Encyclopedia, vol. 6 (New York 1991), 1961-1962.

M. Albert, "Langue et littérature syriaques", in M. Albert et al., eds., Cbristianismes orientaux: Introduction à l'étude des langues et des littératures (Paris 1993) 316, 349-50, et passim.

R. Le Coz, Histoire de l'Eglise d'Orient: Chrétiens d'Irake, d'Iran et de Turquie (Paris 1995), 54.

P. Bettiolo, "VI. Letteratura Siriaca," in A. di Berardino, Patrologia V. Dal Concilio di Calcedonia (451) a Giovanni Damasceno (†750): I Padre 
Orientali (Genoa 2000), 462-465. [Eng. tr.: P. Bettiolo, "VI. Syriac Literature" in A. di Berardino, Patrology V: The Eastern Fathers from the Council of Chalcedon (451) to John of Damascus (†750), tr. Adrian Walford (Cambridge 2006), 458-461.]

C. Capizzi, "Filosseno (Xenajas)" in Dirionario enciclopedico dell'Oriente cristiano (Rome 2000), 306.

J.M. Fiey, "347. Philoxène” in Saints Syriaques (Princeton 2004), 151.

T. Hainthaler, "Philoxenos von Mabbug" in W. Klein, ed., Syrische Kirchenväter (Stuttgart 2004), 180-190.

K.M. Rajan, Calendar of the Syrian Orthodox Church (Kottayam 2004), 40, 64, 83.

S.P. Brock, An Introduction to Syriac Studies, revised $2^{\text {nd }}$ ed., Gorgias Handbooks 4 (Piscataway, NJ 2006), 5, 14.

P. Bruns, "Philoxenos" in H. Kaufhold, Kleines Lexikon des Christlichen Orients (2 Auflage des Kleinen Wörterbuches des Christlichen Orients) (Weisbaden 2007), 409-410.

S.P. Brock, A Brief Outline of Syriac Literature, Moran 'Eth'o 9, $2^{\text {nd }}$ ed. (Kottayam 2009) 31-34, 195-199.

M. Tamcke, Die Christen vom Tur Abdin (Frankfurt am Main 2009), 98-120.

C. Lange and K. Pinggéra, Die altorientalischen Kirchen (Darmstadt 2010), 79, 137.

D.A. Michelson, "Philoxenos of Mabbug" in The Gorgias Encyclopedic Dictionary of the Syriac Heritage (Piscataway, N.J., forthcoming), n.p.

\section{B. Articles in dictionaries and encyclopedias ${ }^{7}$}

[W.] Gass, "Philoxenos", Real-Encyklopädie für protestantische Theologie und Kirche, vol. 11, $1^{\text {st }}$ ed. (1859), 607-609.

E. Venables, "Philoxenos (4) (Xenaias)" in A Dictionary of Christian Biography, Literature, Sects and Doctrines (London, 1880), 391-393.

[W.] Gass, "Philoxenos", Real-Encyklopädie für protestantische Theologie und Kirche, vol. 11, $2^{\text {nd }}$ ed. (1883), 653-655.

7 It should be noted that in their current editions neither the Dictionnaire d'histoire et de géographie ecclésiastiques nor the Reallexikon für Antike und Christentum have reached the volumes for "P"- -thus there is no corresponding entry for Philoxenos. No article was written on Philoxenos in the Dictionnaire d'archéologie chrétienne et de liturgie. 
J.H. Worman, "Philoxenos of Mabug or Hierapolis" in Cyclopedia of Biblical, Theological, and Ecclesiastical Literature, vol. 8 (n.p. 18671887; reprint, Grand Rapids, Mich. 1981), 143.

R. Zöpffel, "Philoxenos (Xenaias)" in Lexikon für Theologie und Kirchenwesen (Braunschweig 1888), 846-847.

"Philoxenos" in Kirchliches Handlexikon, vol. 5 (Leipzig 1897), 313.

G. Krüger, "Philoxenos (Xenaia, Axenaja)" in Realencyklopädie für protestantische Theologie und Kirche, vol. 5, 3rd ed., (Leipzig 1904) 367-70.

V. Schmidt, "Filoxenos" in Kirke-Leksion for Norden, Bind II (Aarhus 1904), 56.

A.A. Vaschalde, "Philoxenos (Akhsenāyā) of Mabbogh" in The Catholic Encyclopedia, vol. XII (New York 1911), 40.

M. Buchberger, "Philoxenos" in Kirchliches Handlexikon, vol. 2 (München 1912), 1482.

R. Abramowski, "Philoxenos (Xenaja)" in Die Religion in Geschichte und Gegenwart, zweite völlig neubearbeitete Auflage, vol. 4 (Tübingen 1930), 1236.

E. Tisserant, "Philoxène de Mabboug" in Dictionnaire de théologie catholique, vol. 12 (Paris 1933) 1509-1532.

A. Rücker, "Philoxenos (Xenaia, Axenaja)" in Lexikon für Theologie und Kirche, vol. 8 (Freiburg im Breisgau 1936) 248-49.

G. Krüger, "Philoxenos (Xenaia, Axenaia)" in The New Schaff-Herzog Encyclopedia of Religious Knowledge, vol. 9 (New York 1949), 43-44.

I. Ortiz de Urbina, "Filosseno di Mabbūg" in Enciclopedia Cattolica, vol. 5 (Vatican City 1950), 1367.

B. Altaner, "8. Philoxenos of Mabbug (Heirapolis)" in Patrology, translated by Hilda C. Graef (Edinburgh 1960), 408. [transl. of art. in Patrologie, $5^{\text {th }}$ German ed., 1958].

B. Spuler, "Philoxenos (= syr. Aksenaja)" in Die Religion in Geschichte und Gegenwart, dritte, völlig neu bearbeitete Auflage, vol. 5 (Tübingen 1961), 357.

O. Bardenhewer, "\$71.2 Philoxenos von Mabbug" in Geschicte der altkirchlichen Literatur: Vierter Band, Das fünfte Jabrhundert mit Einschluß der syrischen Literatur des vierten Jahrbunderts (Darmstadt 1962), 417-421.

A. de Halleux, "Philoxenos (Xenajas)" in Lexikon für Theologie und Kirche 8, $2^{\text {nd }}$ ed. (Freiburg 1963), 479.

J. van der Ploeg, "Philoxenos van Mabboeg" in Romen's Woordenboeken (Roermond en Maaseik 1968), 3871-3872. 
J.G.C. Norman, "Philoxenos" in The New International Dictionary of the Christian Church (Grand Rapids, Mich. 1974), 778.

"Philoxenos" in The Oxford Dictionary of the Christian Church, $2^{\text {nd }}$ ed. (London 1974), 1086.

F. Rilliet, "Filosseno di Mabbug" in Dižionario Patristico e di Antichità cristiane, vol. 1 (Casale Monferrato 1983) 1372-1374.

F. Graffin, "Philoxène de Mabboug" in Dictionnaire de Spiritualité, Ascétique et Mystique, vol. 12 (Paris 1984), 1392-1397.

"Firukusenosu" フィルクセノス (Philóxenos) in Kirisutokyō jinmei jiten キリスト教人名辞典 (Tokyo 1986), 1233b.

F. Drączkowski, "Filoksen, Xenajas" in Encyklopedia Katolicka, vol. 5 (Lublin 1989), 232.

T. Gregory, "Philoxenos of Mabbug" in Oxford Dictionary of Byzantium, vol. 3 (Oxford 1991), 1664.

F. Rilliet, "Philoxenos of Mabbug" in Encyclopedia of the Early Church, vol. 2 (New York 1992), 684. [transl. of art. in Dizionario patristico e di antichità cristiane, 1983 ed.].

"Philoxenos of Mabbug" in The Concise Dictionary of Early Christianity (Collegeville 1992), 139.

E. Kettenhofen, "Philoxenos" in Biographisch-Bibliographisches Kirchenlexicon, vol. VII (Herzberg 1994), 542-549. [Bibliographic updates continue to be made to the online version of this article as of 2010: http://www.bautz.de/bbkl/p/philoxenos.shtml].

"Filoksen," in Khristianstvo: Entsiklopedicheskii Slovar', Tom 3 (Moskva 1995), $121 .{ }^{8}$

A. de Halleux, "Philoxenos von Mabbug" in Theologische Realensyklopädie, vol. XXVI (Berlin: Walter de Gruyter, 1996), 576-580.

"Philoxenos of Mabboug" in Historical Dictionary of the Orthodox Church (Lanham, Md. 1996), 262-263.

S. Ashbrook Harvey, "Philoxenos of Mabbug" in Encyclopedia of Early Christianity, 2nd ed., vol. 2 (New York 1997), 918.

J. Habbi, "Filosseno" in Enciclopedia dei santi, Le Chiese oriental, vol. 1 (Rome 1998), 885-886.

"Philoxenos" in Who's Who in Christianity (New York 1998), 245.

J. Healey, "Philoxenos of Mabbug" in The Blackwell Dictionary of Eastern Christianity (Oxford 1999), 381.

${ }^{8}$ This article cites the following work in relation to Philoxenos, but I was unable to get access to a copy to report its contents: V. Rozhdestvenskii, Bibleiskie Perevody, Siriiskaia Literatura (Moskva 1878). 
J. Martikainen, "Philoxenos (Xenajas)" in Lexikon für Theologie und Kirche vol. 8, $3^{\text {rd }}$ ed. (Freiburg 1999) 262-263.

J. Assfalg, 'Philoxenos v. Mabbug', in Lexikon des Mittelalters, vol. 6 (Stuttgart [1977]-1999) 2105-2106, in Brepolis Medieval Encyclopaedias_Lexikon des Mittelalters Online.

P. Bruns, "Philoxenos of Mabbug" in Dictionary of Early Christian Literature (New York 2000), 486-87. [transl. of art. in Lexikon der antiken christlichen Literatur, 1998, 505-506].

K. Fitschen, "Philoxenos von Mabbug" in Metzler Lexicon Christlicher Denker (Stuttgart 2000), 556.

"Philoxenos" in Dictionary of Christian Biography (New York 2001), 972.

P. Bruns, "Philoxenos von Mabbug" in Lexicon der antiken christlichen Literatur, vol. 3, volst neu bearb. U. erw. Aufl. (Freiburg 2002), 577-578.

M. Tamcke, "Philoxenos von Mabbug" in Religion in Geschichte und Gegenwart, vierte, völlig neu bearbeitete Auflage, vol. 6 (Tübingen 2003), 1317.

G.T. Dennis, "Philoxenos of Mabbugh" in New Catholic Encyclopedia, $2^{\text {nd }}$ ed., vol. 11 (Detroit 2003), 308-309.

C. Kannengeisser, "Philoxenos of Mabbug (CA. 450 - CA. 522)" in Handbook of Patristic Exegesis: The Bible in Ancient Christianity, vol. 2 (Leiden 2004), 1433.

"Philoxenos of Mabbug" in The Westminster Handbook to Patristic Theology (Louisville 2004), 272.

"Philoxenos of Mabbug" in Nelson's Dictionary of Christianity (Nashville 2005), 549.

F. Rilliet, "Filosseno di Mabbug" in Nuovo dizionario patristico e di antichità cristiane, ediziione aggiornata e augmentata (Genova 2007), 19681970.

R.A. Kitchen, "Philoxenos of Mabbug" in The New SCM Dictionary of Church History, vol. 1 (London 2008), 517; [The New Westminster Dictionary of Church History, vol. 1 (Louisville 2008), 517.$]$

D.A. Michelson, "Philoxenos of Mabbug" in The Encyclopedia of Ancient History (New York forthcoming) 


\section{Mention in bibliographic reference works ${ }^{9}$}

C. Moss, Catalogue of Syriac Printed Books and Related Literature in the British Museum (London 1962), 886-891, addenda 187-188.

P. Peterson, ed., Eastern Christianity; A Bibliography Selected from the ATLA Religion Database, revised ed. (N.P. 1984), 408.

K. Frank, Lehrbuch der Geschichte der Alten Kirche (Paderborn 1996), 424.

S.P. Brock, Syriac Studies: A Classified Bibliography (1960-1990) (Kaslik, Lebanon 1996), 244-247.

S.P. Brock, Syriac Studies: A Classified Bibliography (1991-1995), Parole de l’Orient 23 (1998), 329.

S.P. Brock, Syriac Studies: A Classified Bibliography (1996-2000), Parole de l'Orient 29 (2004), 382.

S.P. Brock, Syriac Studies: A Classified Bibliography (2001-2005), Parole de l'Orient 33 (2008), 415.

F. Alpi, La route royale: Sévère d'Antioche et les églises d'Orient (512-518) II: Sources et documents (Beyrouth, 2009), 155.

K. Pinggéra and G. Kessel, "Philoxenos of Mabbug" in A Bibliography of Syriac Ascetic and Mystical Literature (Leiden forthcoming), 183$192 .{ }^{10}$

\section{VITAE AND BIOGRAPHICAL STUDIES}

The standard work on the life, works, and theology of Philoxenos remains the magisterial monograph of A. de Halleux (vide supra, subsequent references to the work of de Halleux will be abbreviated as DH). De Halleux notes that biographical comments can be found in many of the works of Philoxenos and of his contemporaries (such as the letters of Severus or Simeon of Beth

${ }^{9}$ Sergey Minov kindly shared with me an unpublished list of citations from his bibliography on Syriac studies which he is preparing as a database in cooperation with the Center for the Study of Christianity at the Hebrew University. I also benefitted from the fact that the bibliography in E. Kettenhofen's article "Philoxenos" in the BiographischBibliographisches Kirchenlexicon, vol. VII (Herzberg 1994) has continued to be updated in its online version (http://www.bautz.de/bbkl/p/ philoxenos.shtml).

${ }^{10}$ I am grateful to Karl Pingèrra and Gregory Kessel for allowing me to cite an advance copy of their bibliography, a greatly needed first step toward a new clavis for Syriac literature. 
Arsham). Biographical notices, often hostile, can be found in some Byzantine histories and chronicles (cf. Evagrous Scholasticus, Ecclesiastical History, bk. 3, ch. 31 or The Chronicle of Psendo-Joshua the Stylite $\ 30$ or Pseudo-Zacharias). Lastly, Vitae of varying lengths are preserved as Syrian Orthodox hagiographies. Selections of some those works are listed here.

\section{A. ViTAE [DH 3-9]}

\section{(a) "Victory of Mar Aksnoyo"11}

The manuscript containing this vita is a copy commissioned by Mingana from an original in Basibrina, Tur Abdin. The copy was then in the collection of J. Rendel Harris from whence it was sold to Harvard University. Because this manuscript was not included in any of Mingana's manuscript catalogues nor physically present at Selly Oaks both de Halleux and Vööbus assumed it had been lost when they went to look for it half a century later. Fortunately, it is still extant as Harvard MS Syriac 38. It also seems like that the original in Tur Abdin was available to Barsoum whose list of Philoxenos' work relies heavily on it. It may also be the case that Barsoum published an Arabic translation. ${ }^{12}$

Cambridge, Mass. Harvard University, Houghton Library, MS Syriac 38, ff. $111 \mathrm{v}-121 \mathrm{v}$.

An edition of this text has been published in S.P. Brock, "Tash'ita de-Mar Aksnaya," Qolo Suryoyo 110 (July/Aug 1996), 253-244 (sic).

An English translation of this text was published along with citations for smaller biographical notices by Mingana in A. Mingana, "New Documents on Philoxenos of Heirapolis and the Philoxenian Version of the Bible," The Expositor 8.19 [110] (1920), 149-160.

11 Philoxenos was known both as Philoxenos and also as Aksnaya (often rendered Xenias in Latin). In the manuscript tradition his name takes a number of spellings including: محمعس م و.

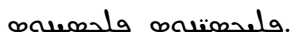

12 The New York Public Library lists the following short item in its online catalogue: E. Barsom, Philoxenos, Bp. of Hierapolis. A Short Account of His Life, Translated from the Syriac into Arabic by Efram Barsom (Dair alZafaran 1911). I was unable to consult this work or locate other copies. 


\section{(b) Elia of Qartmin, "Memra on the Saint Mar Philoxenos of Mabbug”}

Paris, Bibliothèque Nationale, MS Syr 377, ff. 219r-241v.

Edited text and French translation published as A. de Halleux, ed., Éli de Qartmin: Memra sur S. Mar Pbiloxène de Mabbog, CSCO 100-101 (Louvain 1963).

\section{(c) "Qala... Concerning Mar Philoxenos, Bishop of Mabbug of the East"}

Paris, Bibliothèque Nationale, MS Syr 165, f. 237v.

Edited text and French translation published in A. de Halleux, ed., Éli de Qartmin: Memra sur S. Mar Pbiloxène de Mabbog, CSCO 100-101 (Louvain 1963), 21.

\section{(d) [Notice on the Mar Aksnoyo]}

This notice, embedded into the Anonymous Chronicle of 846, is preserved in two versions. De Halleux has proposed that they should be interpreted as a pro-chalcedonian original and an expurgated miaphysite version which portrays Philoxenos in a better light.

St. Catherine's Monastery, Sin. Syr. 10, ff. 48r-49v. [Chalcedonian Original]

London, British Library, MS BL Add. 14,642, ff. 27v.-28r. [Expurgated miaphysite version]

Edited text and French translation of both versions published in A. de Halleux, "À la source d'une biographie expurgée de Philoxène de Mabbog," Orientalia Lovaniensia Periodica 6-7 (1975-1976), 253-66.

Edited text and Latin translation of BL Add. 14,642 published in E.-W. Brooks, ed. and J.-B. Chabot, trans., "Chronicon ad annum domini 846 pertinens," in I. Guidi, ed., Chronica Minora, CSCO, Scriptores Syri Ser. 3, t. 4 (Paris 1903), textus 220-221, versio 168.

Edited text and French translation of BL Add. 14,642 published as F. Nau, "Notice inédite sur Philoxêne, évêque de Maboug," Revue de l'Orient chrétien 8 (1903), 630-633.

(e) "Mar Philoxenos Bishop of Mabug, Wise in God and Enlightened in Knowledge"

Vatican City, BAV, MS Vat. Syr. 155 f. 5r.

Edited text published in Three Letters of Philoxenos, Bishop of Mabbogh (485519): Being the Letter to the Monks, the First Letter to the Monks of Beth-Gaugal, and the Letter to Emperor Zeno, edited and translated by Arthur Adolphe Vaschalde (Roma 1902), 175-176. 


\section{(f) Additional Vitae}

A number of other manuscripts with vitae or biographical notices have been identified in A. Vööbus, "La biographie de Philoxène. Tradition des manuscrits," Analecta Bollandiana 93 (1975), 111114. These remain as yet unpublished.

\section{B. BIOGRAPHICAL STUDIES}

\section{i. Monographs}

I. Yacoub III, Mysteries in the struggle of Saint Philoxenos of Mabboug [in Arabic], (Damascus, 1970) [non-vidi].

A. de Halleux, Philoxène de Mabbog: Sa vie, ses écrits, sa theologie (Louvain 1963).

\section{ii. Articles}

Several of the longer articles listed above in section II are worth consulting as biographical studies, especially:

T. Hainthaler, "Philoxenos von Mabbug" in W. Klein, ed., Syrische Kirchenväter (Stuttgart 2004), 180-190.

A. de Halleux, "Philoxenos von Mabbug" in Theologische Realensyklopädie, vol. XXVI (Berlin: Walter de Gruyter, 1996), 576-580.

F. Graffin, "Philoxène de Mabboug" in Dictionnaire de Spiritualité, Ascétique et Mystique, vol. 12 (Paris 1984), 1392-1397.

A. I. Barsoum, The Scattered Pearls: The History of Syriac Literature and Sciences, tr., Matti Mousa, 2nd Rev. Ed. (Piscataway, N.J. 2003) 262-270 [Originally published in Arabic in 1956].

E. Tisserant, "Philoxène de Mabboug" in Dictionnaire de théologie catholique, vol. 12 (Paris 1933) 1509-1532.

J.S. Assemanus, Bibliotheca Orientalis Clementino-Vaticana II (Rome 1719) $10 \mathrm{~b}-46 \mathrm{a}$.

\section{SURVEY OF THE WORKS Attributed to Philoxenos}

In this section I have attempted to provide standardized English titles. Already half a century ago, de Halleux had lamented that many of the works of Philoxenos are known by western names (such as the Tractatus Tres) that do not reflect how the work was known in the time of Philoxenos or in the manuscript traditions (e.g. The Book of Sentences). My main aim has been to aid those attempting to identify new fragments of Philoxenos in recently catalogued manuscripts. Accordingly, I have whenever possible 
attempted to mirror in English the title given in the manuscripts. I also have in preparation, but not ready for publication a list of titles, incipits and varients in Syriac. ${ }^{13}$ In this clavis, when the title in the manuscript has been too incomplete (or occasionally when it has not accurately reflected the nature of the work) I have offered suggestions. To aid in navigating the clavis, each Philoxenian title is also sequentially numbered. Because much of the work in de Halleux's monograph remains essential the corresponding page number in de Halleux is also given with the abbreviation DH. (Unfortunately the works in de Halleux are not given a complete sequential numbering and most of the spuria and dubia are not presented systematically at all. They are offered systematically below after extant and lost works.) Finally, I have retained the order in which de Halleux has presented the works because this will most easily assist the reader in using this clavis in conjunction with de Halleux. I have, however, abandoned the thematic classification of the works as exegetical, dogmatic, and spiritual which de Halleux inherited from Tisserant. As I have argued elsewhere, this distinction adds an artificial division into the holistic vision of churchmanship in Philoxenos' works where he blended the fight against Christological error, the pursuit of asceticism, and the contemplation and interpretation of the Biblical text into a unified spiritual endeavor.

\section{A. EXTANT WORKS AND FRAGMENTS}

\section{(1) The Philoxenian New Testament and Bible [DH 115] ${ }^{14}$}

No copies survive of the translation of the New Testament commissioned by Philoxenos and undertaken by his corepiscopos Polycarp. The history of the Philoxenian has largely been eclipsed by that of the later Harklean version. Identifying fragments of the

13 As noted above, this current clavis is an initial draft of an interactive online clavis I am preparing that will eventually collect into a searchable database the Syriac wording for all of the incipits, attributions, and subscriptions related to Philoxenos in the manuscript tradition.

14 I reiterate my earlier statement that a comprehensive treatment of the scholarship on the Philoxenian New Testament would require a separate clavis, most likely to be done by a Biblical scholar. Instead, I have merely presented the primary and most recent works here and refer the reader to them for further orientation. 
Philoxenian has been a contentious topic of scholarly debate. Indeed, references to the Philoxenian in secondary literature made prior to 1981 should be treated cautiously. Since 1981, the problem of the Philoxenian and Harklean has been successfully resolved by S.P. Brock. For which see:

Tjitze Baarda, "The Syriac Versions of the New Testament," in B.D. Ehrman and M.W. Holmes, eds., The Text of the New Testament in Contemporary Research. Essays on the Status Quaestionis (Grand Rapids, Mich. 1995), 97-112.

S.P. Brock, "The Resolution of the Philoxenian/Harclean Problem," in E.J. Epp and G.D. Fee, eds., New Testament Textual Criticism. Its Significance for Exegesis. Essays in honor of Bruce M. Metżger (Oxford: Clarendon Press, 1981), 325-343.

Material from the Philoxenian New Testament (collected fragments and an analysis of the reception history) is available in the following works inter alia:

J.E. Walters, "The Philoxenian Gospels as Reconstructed from the Writings of Philoxenos of Mabbug," Hugoye 13:2 (2010), 57-129.

J.E. Walters, The Pbiloxenian Gospels as Reconstructed from the Exegetical Writings of the Philoxenos of Mabbug, M.A. Thesis, Abilene Christian University (Abilene 2009).

R.B. ter Haar Romeny, "A Philoxenian-Harclean Tradition? Biblical Quotations in Syriac Translations from Greek" in W.J. van Bekkum et al, eds., Syriac Polemics: Studies in Honour of Gerrit Jan Reinink, Orientalia Lovaniensia Analecta 170 (Leuven 2007), 59_ 76.

B. Aland, "Monophysitismus und Schriftauslegung. Der Kommentar zum Matthäus und Lukasevangelium des Philoxenos von Mabbug," in Unser ganzes Leben Christus unserm Gott überantworten. Studien zur ostkirchlichen Spiritualität. Fairy von Lilienfeld zum 65. Geburtstag, ed. P. von Hauptmann (Göttingen: Vandenhoeck \& Ruprecht, 1982), 142-66.

B. Aland, "Die Philoxenianische-Harklensische Übersetzungstradition," Le Muséon 94.3 (1981), 321-83.

S.P. Brock, "Syriac Euthalian Material and the Philoxenian Version of the New-Testament," Zeitschrift fir die Neutestamentliche Wissenschaft und die Kunde der Alteren Kirche 70.1 (1979), 120-130.

J. Gwynn, Remnants of the Later Syriac Versions of the Bible, 2 vols. (London 1909). 
Readers are also advised that the version published as J. White, Sacrorum evangeliorum, actorum apostolorum et epistolarum tam catholicorum quam paulinarum versio syriaca pbiloxeniana (Oxford 1778-1803) is not the Philoxenian but the Harklean version.

There is slight evidence for a version of at least some Old Testament books (Genesis, Exodus, Isaiah and, possibly but less likely, Psalms) to which the name of Philoxenos could be attached, though the authenticity of this attribution remains open to question given the paucity of evidence available. Relevant material (collected fragments and an analysis of the reception history) is available in the following works inter alia:

R.J.V. Heibert, "The Place of the Syriac Versions in the Textual History of the Psalter" in P.W. Flint and P.D. Miller, eds., The Book of Psalms: Composition and Reception (Leiden 2005), 505-536.

R.G. Jenkins, "Quotations from Genesis and Exodus in the Writings of Philoxenos of Mabbug," Studia Patristica 18:4 (1990), 245-248.

R.G. Jenkins, The Old Testament Quotations of Pbiloxenos of Mabbug, CSCO 514/Subs. 84 (Louvain 1989).

R.G. Jenkins, "Some Quotations from Isaiah in the Philoxenian Version," Abr-Nabrain 20 (1981-1982), 20-36.

\section{(2) "Memra on the Theoria of the Tree of Life" [DH 126] ${ }^{15}$}

This letter is preserved in citations by Moses Bar Kepha. Barsoum also reports that it is quoted in a Dayr al-Za'faran MS (no. 223) containing the works of John of Dara.

Fragments preserved in several MSS, most notably in Moses Bar Kepha's On Paradise in New Haven, Conn., Yale University, Beinecke MS Syriac 10.

${ }^{15}$ Yonatan Moss at Yale University is preparing an edition of these fragments and kindly shared a copy of his work in progress with me. It may also be that an additional fragment is transmitted in Bar Kepha's "On the Soul," preserved in Birmingham, University of Birmingham, Mingana Collection, MS Syriac 9, which I was not able to inspect. I was unable to find any fragments in the version of Bar Kepha's "On the Soul" published as Moses Bar-Kepha und sein Buch von der Seele, trans. Oskar Braun (Freiburg 1891). Based on the comments of Barsoum and others it seems likely that as we are able to identify further manuscripts of Bar Kepha they may hold additional Philoxenian citations. 
Latin version of the fragments are published in Commentaria de Paradiso, ed. A. Masius in J.-P. Migne, ed., Patrologiae Graeca, vol. 111 (Paris, 1863), cols. 479-608, reprinted from A. Masius, De Paradiso commentarius, scriptus ante anno prope septingentos à Mose Bar-Cepha Syro, episcopo in Beth-Raman, \& Beth-Ceno, ac curatorum rerum sacrarum in Mozal, hoc est Selencia Parthorum (Antverpix 1569).

Cf. I.A. Barsoum, The Scattered Pearls: The History of Syriac Literature and Sciences, $2^{\text {nd }}$ Rev. Ed. (Piscataway, N.J. 2003), 269.

\section{(3) "Commentary" [on Matthew and Luke] [DH 128]}

This text has been published in two English versions. The critical edition of Watt is preferred due to being both more complete and a true edited text (as opposed to the emmended facsimile edition of Fox which is unsatisfactory in its attempt to be simultaneously an accurate facsimile and a critical edition).

Fragments preserved in several MSS, most notably, London, British Library, MS BL Add. 17,126, ff. 1r-10v, 14r-38v.

Facsimile text of MS BL Add. 17,126 with conjectural emendations and English translation published in Douglas J. Fox, The "MatthewLuke Commentary" of Philoxenos: Text, Translation, and Critical Analysis (Missoula, Mont. 1979).

Edited fragments from MS BL Add. 17,126 and other MSS with English translation published as Fragments of the Commentary on Matthew and Luke, edited by J. W. Watt, CSCO 392-93 (Louvain 1978).

Edited fragment and German translation published as "Der Sermo des Philoxenos von Mabbug De annuntiatione Dei Genetricis Mariae," edited by Paul Krüger, Orientalia Christiana Periodica 20, 1-2 (1954), 153-165.

N.B.: Review of these editions and translations in A. de Halleux, "Le Commentaire de Philoxène sur Matthieu et Luc," Le Muséon 93 (1980), 5-35.

\section{(4) "Commentary" [on the Prologue of John] [DH 150]}

London, British Library, MS BL Add. 14,534, ff. 1r-199v and possibly MS BL Add. 17,126, ff. 11-13.

Edited text and French translation of BL Add. 17,126, ff. 11-13 published in A. de Halleux, "Le Commentaire de Philoxène sur Matthieu et Luc," Le Muséon 93 (1980), 5-35. 
Edited text and French translation of BL Add. 14,534 published as Commentaire du prologue jobannique (Ms. Br. Mus. Add. 14,534), edited and translated by André de Halleux, CSCO 380-81 (Louvain 1977).

(5) "We Believe in the Trinity of One Eternal Nature" [DH 170]

Multiple MSS including London, British Library, MS BL Add. 17,201, f. $6 \mathrm{rb}-\mathrm{vb}$ which provides evidence of the antiquity $\left(6-7^{\text {th }}\right.$ century MS) of this text.

(6) "Letter to the Emperor Zeno Concerning the Embodiment and Inhomination [Rhouristos] of God the Word" [DH 171]

De Halleux suggested that this work should more properly classified as a profession of faith rather than a letter.

Vatican City, BAV, MS Vat. Syr. 135 ff. 17ra-19vb.

Edited text based on edition of Vaschalde with Arabic translation

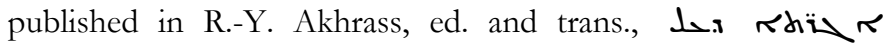

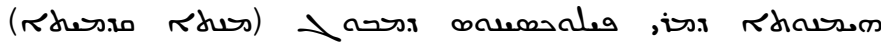
(Ma'arret Saidnaya 2007), 193-218.

Edited text and English translation published in Three Letters of Philoxenos, Bishop of Mabbogh (485-519): Being the Letter to the Monks, the First Letter to the Monks of Beth-Gangal, and the Letter to Emperor Zeno, edited and translated by Arthur Adolphe Vaschalde (Roma 1902), 118-26, 163-73.

(7) "Reply When Someone is Asked 'How Do You Believe?': My Faith is in the Trinity" [DH 173]

Fragments in two MSS. ${ }^{16}$

Edited fragment and German translation based on MS BL Add. 14,670 published in P. Krüger, "Philoxeniana inedita," Oriens Christianus 48 (1964), 157-161.

Edited text based on MS BL Add. 14,529 published in E.A. Wallis Budge, The Discourses of Philoxenos, Bishop of Mabbôgh, A.D. 485-519, vol. 2 (London 1894), xcvi-xcviii.

${ }^{16}$ While I have attempted to present the salient manuscript citations, the reader is referred to the relevant section in de Halleux for further manuscript documentation. 


\section{(8) "Response of Philoxenos" [to John II of Alexandria?] [cf. DH 173-175]}

The fragment is acephalous and found in only one manuscript (a manuscript which contains two other Philoxenian fragments, (and a discourse by John of Alexandria). At the end of the fragment is an attribution which can be taken as either a subscription to it or a title for the subsequent section of the

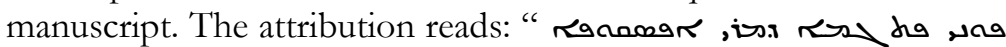

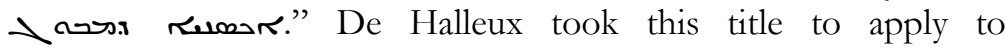
subsequent text and thus did not discuss this fragment. Subsequently, P. Krüger observed that the other two Philoxenian fragments in the manuscript appear to have subscriptions, hence the attribution in question should also be taken as a subscription.

Fragment preserved in London, British Library, MS BL Add. 14,670, ff. $19 \mathrm{r}-20 \mathrm{v}$.

Edited text and German translation published in P. Krüger, "Philoxeniana inedita," Oriens Christianus 48 (1964), 150-157.

(9) "Catalogue of the Heresies which Hold to Error" or "Catalogue of All Heresies" [DH 175]

Three MSS.

Edited text and French version published in F. Nau, "Documents pour server à l'histoire de l'Église Nestorienne," Patrologia Orientalis 13.2 (Paris 1919), 248-249.

Edited text and English translation published in E.A. Wallis Budge, The Discourses of Pbiloxenos, Bishop of Mabbôgh, A.D. 485-519, vol. 2 (London 1894), cxxxvi-xxxviii, xlv-xlviii.

(10) "We Confess Three Divine Persons, One God" [DH 176]

Paris, Bibliothèque Nationale, MS Syr 112, f. 278r-v.

Edited text and French version published in F. Nau, "Documents pour server à l'histoire de l'Église Nestorienne," Patrologia Orientalis 13.2 (Paris 1919), 250-251.

(11) [Six or Seven] "Particular Chapters" [that We Should Anathematize Each One Who is Nestorian] [DH 179]

Two MSS; similar texts but different numeration such that one has six and the other seven chapters.

London, British Library, MS Add. 14,604, ff. 67r-68r (six chapters).

London, British Library, MS Add. 14,529, ff. 66v-68r (seven chapters). 
Edited text and partial English translation of BL MS Add. 14,529 published in E.A. Wallis Budge, The Discourses of Pbiloxenos, Bishop of Mabboghb, A.D. 485-519, vol. 2 (London 1894), cxx-cxxiii, xxxvii-xxxix.

(12) [Seven] "Chapters Against Those Who Say that It Is Fitting that the Evil Portion of the Doctrines of the Heretics Should Be Anathematized, But that It Is Not at All Right that They Should Be Rejected with Their Whole Doctrine" [DH 181 $]^{17}$

London, British Library, MS Add. 14,604, ff. 113ra-115rb.

(13) [Three] "Primary Chapters Against the Heresies that Wage War with the Church" [DH 182]

London, British Library, MS Add. 14,529, f. 69rb-vb.

(14) [Twelve] "Chapters Against Those Who Say Two Natures in Christ and One Person" [DH 183]

London, British Library, MS Add. 14,597, ff. 91rb-98vb.

Fragment in London, British Library, MS Add. 17,201 , ff. 14rb-15ra.

Edited text based on MS Add. 14,597 published in E.A. Wallis Budge, The Discourses of Philoxenos, Bishop of Mabbôgh, A.D. 485-519, vol. 2 (London 1894), civ-cxx.

(15) “Twenty Chapters Against Nestorius" [DH 185]

London, British Library, MS Add. 14,597, ff. 98vb-105va.

Edited text and partial English translation published in E.A. Wallis Budge, The Discourses of Pbiloxenos, Bishop of Mabbôgh, A.D. 485-519, vol. 2 (London 1894), cxxiii-cxxxvi, xxxix-xliv.

(16) "Ten Chapters against those Who Divide Our Lord after His Indivisible Union" [DH 186]

London, British Library, MS Add. 14,597, ff. 105va-107va.

Edited text and summary English translation published in E.A. Wallis Budge, The Discourses of Philoxenos, Bishop of Mabbôgh, A.D. 485519, vol. 2 (London 1894), c-civ, xxxvi-xxxvii.

(17) "Letter to the Monks on Faith" [DH 189]

Multiple MSS.

17 Volker Menze and I have prepared a draft edition and translation of this work which we are planning to publish at a future date. 
Edited text based on editions of Vaschalde and Graffin with Arabic translation published in R.-Y. Akhrass, ed. and trans., raiz r

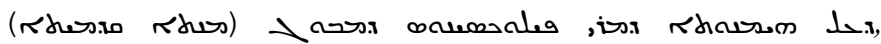
(Ma'arret Saidnaya 2007), 21-64.

Edited text and French translation published in Sancti Pbiloxeni Episcopi Mabbugensis dissertationes decem de uno e sancta trinitate incorporato et passo (Memre contre Habib), edited and translated by M. Brière and F. Graffin, PO 41.1. (Turnhout, Belgium 1982), 38-57.

Edited text and English translation published in Three Letters of Pbiloxenos, Bishop of Mabbogh (485-519): Being the Letter to the Monks, the First Letter to the Monks of Beth-Gaugal, and the Letter to Emperor Zeno, edited and translated by Arthur Adolphe Vaschalde (Roma 1902), 93-105, 127-45.

\section{(18) [First] "Letter to the Monks of Teleda" [DH 192] $]^{18}$}

Vatican City, BAV, MS Vat. Syr. 136 ff. 3ra-29rb and fragments in other MSS.

Edited text based on edition of Guidi with Arabic translation published in

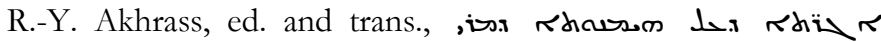

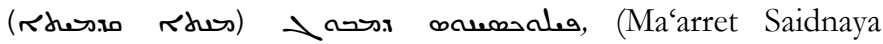
2007), 65-192.

Edited selections from the edition of Guidi and a facsimilie of one folio published in H. Gismondi, Linguae syriacae grammatica et chrestomathia cum glossario scholis accommodata (Beirut 1900), 130$140,166$.

Edited text based on Vat. Syr. 136 and BL Add. 14,663 with Italian summary published as La lettera di Filosseno: Ai monaci di Tell'addâ (Teleda), Memoria del socio Ignazio Guidi, edited by I. Guidi (Roma 1886).

Partial edited text (one folio) from Vat. Syr. 136 published in I. Guidi, "Mundhir III. und die beiden monophysitischen Bischöfe," Zeitschrift der Deutschen Morgenländischen Gesellschaft 35 (1881), 142 145.

\section{(19) "Letter to the Arzonites" [DH 196]}

A fragment cited in Vatican City, BAV, MS Vat. Syr. 135 f. 89ra-b.

${ }^{18}$ I am currently preparing an English translation of this work. 


\section{(20) "Letter Concerning Zeal" [to the Monks of Amida] [DH 197]}

Fragment in multiple MSS.

Edited text based on edition of Vööbus and Nau with Arabic translation published in R.-Y. Akhrass, ed. and trans., 1 . (Rherid Rhus) خasis onearaleg, (Ma'arret Saidnaya 2007), 74-80.

Edited text and English translation in A. Vööbus, Syriac and Arabic Documents Regarding Legislation Relative to Syrian Asceticism (Stockholm: ETSE, 1960), 51-54.

French translation based on Paris, Bibliothèque National, MS Syr. 62, f. $218 \mathrm{v}$ in F. Nau, "Literature canonique syriaque inédite, I," Revue de l'Orient chrétien 14 (1909), 37-38.

Cf. A. Vööbus, History of Asceticism in the Syrian Orient. A Contribution to the History of Culture in the Near East, III, CSCO, Subsidia, 81 (Louvain 1988), 123-142, 170-172.

Cf. A. Vööbus, Syrische Kanonessammlungen, I. Westsyrische Originalurkunden I. B, CSCO, Subsidia, 38 (Louvain 1970), 316-325.

\section{(21) "First Letter to the Monks of Beth Gogal" [DH 198]}

Vatican City, BAV, MS Vat. Syr. 135 ff. 19vb-23vb.

Edited text based on edition of Vaschalde with Arabic translation

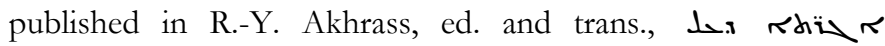

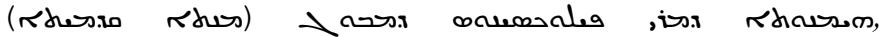
(Ma'arret Saidnaya 2007), 219-258.

Edited text and English translation in Three Letters of Philoxenos, Bishop of Mabbogh (485-519): Being the Letter to the Monks, the First Letter to the Monks of Beth-Gangal, and the Letter to Emperor Zeno, edited and translated by Arthur Adolphe Vaschalde (Roma 1902), 105-118, 146-162.

\section{(22) "Second Letter to the Monks of Beth Gogal" [DH 201]}

Vatican City, BAV, MS Vat. Syr. 136 ff. 35vb-53rb.

Edited text based on edition of de Halleux with Arabic translation published in R.-Y. Akhrass, ed. and trans., 2 .

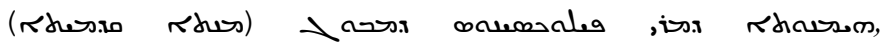
(Ma'arret Saidnaya 2007), 259-370.

Edited text and French translation published as "La deuxième lettre de Philoxène aux monastères du Beit Gaugal,” edited and translated by André de Halleux, Le Muséon 96, 3-4 (1983), 5-79. 


\section{(23) "Letter to Abu Ya'fur" [DH 203]}

This text enjoys a contentious secondary literature and a complex manuscript history due to the clear interpolation of a section about the history of the Turks in the text. There are at least three main versions of the text. Given the contentious manuscript history of this text, a full listing of known MSS is given here in the hopes that further work will be done or new copies discovered. ${ }^{19}$ Some introduction to the literature and the history of the text are found in the following:

M. Dickens, Turkajye: Turkic Peoples in Syriac Literature prior to the Seljuiks, $\mathrm{PhD}$ thesis, University of Cambridge, 2008, 227-236.

S.P. Brock, "Alphonse Mingana and the Letter of Philoxenos to Abu 'Afr," Bulletin of the John Rylands Library 50 (1967), 199-206.

MSS which have been edited:

Beirut, Daroun Harissa, Library of the Syro-Catholic Patriarchate at Sharfeh, MS Rahmani 115 ff. 103v-123v.

Birmingham, University of Birmingham, Mingana Collection, MS Syriac 71, ff. 40r-47r.

London, British Library, MS Add. 14,529, ff. 61ra-65va.

London, British Library, MS Add. 17,134, f. 4v.

London, British Library, MS Add. 17,193, f. 83r-v.

Manchester, John Rylands Library, MS Syr. 59, ff. 105r-113v.

MSS with content unknown:

Beirut, Daroun Harissa, Library of the Syro-Catholic Patriarchate at Sharfeh, MS Rahmani 178, ff. 1v-27r.

Barsoum reports (without a citation) that a manuscript in the Syrian Orthodox patriarchal library (then at Homs) contains the work including the interpolation. He also mentions a connection to a similar Armenian account. This manuscript cannot be identified as among those presently listed in current catalogue (1994) of the patriarchal library in Damascus.

Editions and literature:

Edited text based on editions of Martin, Mingana, and Harb with Arabic translation published in R.-Y. Akhrass, ed. and trans., rhiz

${ }^{19}$ Muriel Debié announced in a presentation at the 2008 Symposium Syriacum in Grenada that she was preparing some of the texts in Sharfeh MS. 178. Mark Dickens has indicated tentative plans for editing the fragments on the Turks pending access to the MSS. 


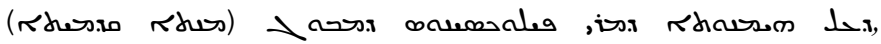
(Ma'arret Saidnaya 2007), 371-428.

Edited text and French translation based on MS Sharfeh 115 published as "Lettre de Philoxène de Mabbūg au phylarque Abū Ya fūr de Hìrtā de Bētna'mān (selon le manuscrit no $115 \mathrm{du}$ fond patriarcat de Šarfet)," edited and translated by Paul Harb, Melto 3, 1-2 (1967), 183-222.

Partial edition and partial English translation based on MS John Rylands 59 published in Alphonse Mingana, "The early spread of Christianity in Central Asia and the Far East: A New Document," Bulletin of the John Rylands Library 9.2 (July, 1925), 343-367.

French translation based on edition of Martin published as "La lettre de Philoxène à 'Abou-Niphir," translated by J. Tixeront, Revue de l'Orient chrétien 8 (1903), 623-30.

Edited text based on MS British Library 14529 published in P. Martin, Syro-chaldaicae institutiones, seu introductio practica ad studium linguae aramaeae (Paris 1873), 71-78.

Cf. I.A. Barsoum, The Scattered Pearls: The History of Syriac Literature and Sciences, $2^{\text {nd }}$ Rev. Ed. (Piscataway, N.J. 2003), 269.

\section{(24) "Letter to the Monks of Palestine on Faith" [DH 208]}

London, British Library, MS Add. 14,532, ff. 178va-181vb.

Edited text based on edition of de Halleux with Arabic translation published in R.-Y. Akhrass, ed. and trans., 2 .

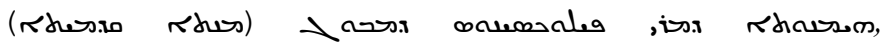
(Ma'arret Saidnaya 2007), 429-456.

Edited text and French translation published in "Nouveaux textes inédits de Philoxène de Mabbog: I. Lettre aux moines de Palestine -Lettre Liminaire au Synodicon d'Éphèse," edited and translated by A. de Halleux, Le Muséon 75, 1-2 (1962), 31-62.

\section{(25) "Letter Placed at the Beginning of the Synodicon" [DH 208]}

London, British Library, MS Add. 14,533, f. 168r.

Edited text based on edition of de Halleux with Arabic translation

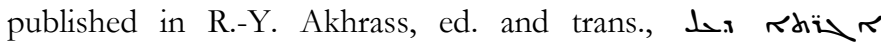

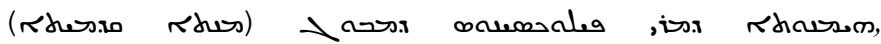
(Ma'arret Saidnaya 2007), 457-460.

Edited text and French translation published in "Nouveaux textes inédits de Philoxène de Mabbog: I. Lettre aux moines de Palestine- 
Lettre Liminaire au Synodicon d'Éphèse," edited and translated by André de Halleux. Le Muséon 75, 1-2 (1962), 31-62.

(26) "Letter to Abbots Theodore, Mamas, and Severus" [DH 209] ${ }^{20}$

Fragments in London, British Library, MS Add. 12,155, f. 41ra-b.

Fragments in London, British Library, MS Add. 14,532, f. 8rb.

(27) “Letter Against Flavian of Antioch" [DH 210]

Fragments in London, British Library, MS Add. 12,155, f. 41rb.

Fragments in London, British Library, MS Add. 14,532, ff. 7vb-8ra.

(28) “Letter to the Lector Maron of Anazarbus" [DH 211]

London, British Library, MS Add. 14,726, ff. 19v-24v.

Edited text based on edition of Lebon with Arabic translation published in R.-Y. Akhrass, ed. and trans., ,

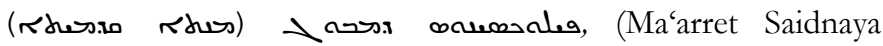
2007), 461-522.

Edited text and Latin translation published in "Textes inédits de Philoxène de Mabboug," edited and translated by J. Lebon. Le Muséon 43, 1-2 (1930), 17-84.

(29) "Letter to the Scholasticus Uranius" [ - iar] [DH 214]

Single fragment preserved in multiple MSS.

(30) “Letter to John the Arab" [DH 216]

Single fragment preserved in multiple MSS.

(31) "Second letter to the Monks of Teleda" [DH 217, cf. 188]

De Halleux has identified a series of fragments as a second letter to the Monks of Teleda. It should be noted that the document identified by Assemani as the Second Letter to the Monks of Teleda is in fact the Letter to the Monks on Faith (no. 17 supra).

Multiple fragments preserved in anti-Julianist MSS, most notably in London, British Library, MS Add. 14,529, ff. 14vb-15va.

(32) "Letter to the Monks in Defense of Dioscorus, that $\mathrm{He}$ Canonically Received Eutyches" [DH 220]

Fragment preserved in London, British Library, MS Add. 12,155, f. 163 ra.

${ }^{20} \mathrm{I}$ am in the process of collecting most of the smaller fragments identified in the clavis and plan to publish them with an English translation. 
Edited text based on edition of Lebon with Arabic translation published

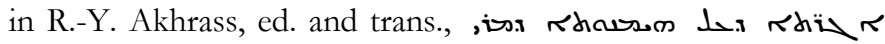

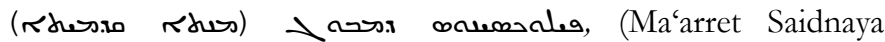
2007), 523-528.

Edited text and Latin translation published in "Textes inédits de Philoxène de Mabboug," edited and translated by J. Lebon. Le Muséon 43, 1-2 (1930), 57, 83-83.

(33) "Letter on the Monks of the Orient" or "Letter on the Economy of the Church" [DH 220]

Six fragments preserved with varying titles in London, British Library, MS Add. 14,533, ff. 50ra-52ra, 169vb-170ra, 184rb.

Edited text based on edition of Lebon and de Halleux with Arabic translation published in R.-Y. Akhrass, ed. and trans., Rdil $\approx$

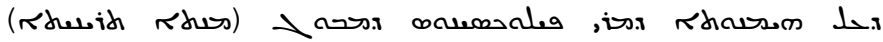
(Ma'arret Saidnaya 2007), 35-73.

3 fragments edited with French translation published as "Lettre aux moines orthodoxes d'Orient" in "Nouveaux textes inédits de Philoxène de Mabbog: II. Lettre aux moines d'orient," edited and translated by André de Halleux, Le Muséon 76 (1963), 5-26.

3 fragments edited with Latin translation published in "Textes inédits de Philoxène de Mabboug," edited and translated by J. Lebon, Le Muséon 43, 1-2 (1930), 175-220.

(34) "Letter on Ecclesiastical Affairs to Simeon, Abbot of Teleda" [DH 222]

London, British Library, MS BL Add. 14,533, ff. 48va-50ra.

Edited text based on edition of Lebon with Arabic translation published in R.-Y. Akhrass, ed. and trans., ,

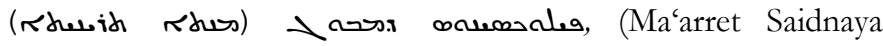
2007), 3-34.

Edited text and Latin translation published in "Textes inédits de Philoxène de Mabboug," edited and translated by J. Lebon, Le Muséon 43, 3-4 (1930), 167-193.

Partial edited text and Latin translation published in J. Lebon, Le Monophysisme Sévérien (Louvain 1909), B1-4 [553-555].

\section{(35) "Letter to the Monks of Senun" [DH 223]}

Inter alia this text is notable for the patristic florilegium embedded in the middle of the text (see pp. 32-51 of the edition below). Vatican City, BAV, MS Vat. Syr. 136, ff. 58vb-130vb. 
London, British Library, MS BL Add. 14,597, ff. 35vb-91ra.

Edited text based on edition of de Halleux with Arabic translation published in R.-Y. Akhrass, ed. and trans., ה ז

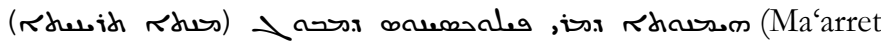
Saidnaya 2007), 81-354.

Edited text and French translation based on both MSS published as Lettre aux moines de Senoun, edited by André de Halleux, CSCO 231-32 (Louvain 1963).

Partial French translation of MS BL 14597 published as "Lettre de Nestorius aux habitants de Constantinople, d'après Philoxène de Mabboug," in F. Nau, ed. and trans., Nestorius: Le Livre d'Héraclide de Damas, traduit en francais, suivi du texte grec des trois homélies de Nestorius sur les tentations de Notre-Seigneur et de trois appendices: Lettre à Cosme, présents envoyés d'Alexandrie, lettre de Nestorius aux babitants de Constantinople (Paris 1910), 370-373.

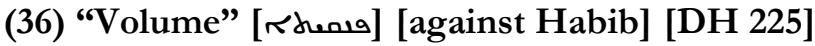

This volume, preserved in multiple MSS but primarily MS BL Add. 12,164 and Vat. Syr. 138, contains several works which together document a debate between Philoxenos and a dyophysite monk, Habib. The individual works are:

\section{(36a) [Ten Memre against Habib]}

Memre against Habib (I-II): edited text and Latin translation published as Sancti Philoxeni episcopi Mabbugensis dissertationes decem de uno e sancta trinitate incorporato et passo, edited and translated by Maurice Brière, PO 15.4 (Turnhout, Belgium 1920).

Memre against Habib (III-V): edited text and Latin translation published as Sancti Pbiloxeni episcopi Mabbugensis dissertationes decem de uno e sancta trinitate incorporato et passo, edited and translated by M. Brière and F. Graffin, PO 38.3 (Turnhout, Belgium 1977).

Memre against Habib (VI-VIII): edited text and French translation published as Sancti Pbiloxeni episcopi Mabbugensis dissertationes decem de uno e sancta trinitate incorporato et passo, edited and translated by M. Brière and F. Graffin, PO 39.4 (Turnhout, Belgium 1979).

Memre against Habib (IX-X): edited text and French translation published as Sancti Pbiloxeni episcopi Mabbugensis dissertationes decem de uno e sancta trinitate incorporato et passo, edited and translated by M. Brière and F. Graffin, PO 40.2. (Turnhout, Belgium 1980). 


\section{(36b) [Chapters of Habib] or "Mamlla of the Adversary"}

This text is a selection of quotations from Habib's Mamlla compiled by Philoxenos and interspersed with critical comments.

Edited text and French translation published in Sancti Pbiloxeni episcopi Mabbugensis dissertationes decem de uno e sancta trinitate incorporato et passo (Memre contre Habib), edited and translated by M. Brière and F. Graffin, PO 41.1.186 (Turnhout, Belgium 1982), 5-33.

\section{(36c) [Brief Refutation]}

The chapters are followed by a brief refutation by Philoxenos.

Edited text and French translation published in Sancti Philoxeni episcopi Mabbugensis dissertationes decem de uno e sancta trinitate incorporato et passo (Memre contre Habib), edited and translated by M. Brière and F. Graffin, PO 41.1.186 (Turnhout, Belgium 1982), 32-37.

(36d) "Letter to the Monks on Faith" [same as no. 17 supra]

The volume then includes the Letter to the Monks on Faith as the occasion for Habib's Mamlla.

Edited text and French translation published in Sancti Pbiloxeni Episcopi Mabbugensis dissertationes decem de uno e sancta trinitate incorporato et passo (Memre contre Habib), edited and translated by M. Brière and F. Graffin, PO 41.1. (Turnhout, Belgium 1982), 38-57.

\section{(36e) "Testimonies Written by the Fathers" [Florilegium]}

The volume concludes with a lengthy Florilegium compiled by Philoxenos.

Complete edited text and French translation published in Sancti Pbiloxeni episcopi Mabbugensis dissertationes decem de uno e sancta trinitate incorporato et passo (Memre contre Habib), edited and translated by M. Brière and F. Graffin, PO 41.1.186 (Turnhout, Belgium 1982), 58-129.

Many of the citations of the florilegium were published in piecemeal fashion according to attribution in various earlier publications. Partial edited text and French translation (for the citations of Ephrem) published with commentary and bibliography concerning previous partial editions in F. Graffin, "Le florilège patristique de Philoxène de Mabbog," in I. Ortiz de Urbina, ed., Symposium Syriacum, 1972 (Roma 1974), 267-290.

\section{(37) "Memra on the Hymn Holy Art Thou God" [On the Trisagion] [DH 238]}

Three fragments preserved in multiple anti-Julianist MSS. 


\section{(38) "The Book of Sentences" [DH 240]}

Primarily preserved in Vatican City, BAV, MS Vat. Syr. 137.

Edited fragment and German translation based on MS BL Add. 14,670 published in Edited text and German translation published in P. Krüger, "Philoxeniana inedita," Oriens Christianus 48 (1964), 161-162. [The hypothesis that this fragment belongs to the Book of Sentences is that of de Halleux not Krüger.]

Short excerpt translated into English in W.A. Wigram, The Separation of the Monophysites (London 1923), 202-203.

Edited text and Latin translation based on MS Vat. Syr. 137 published as Tractatus tres de trinitate et incarnatione, edited and translated by Arthur Adolphe Vaschalde, CSCO 9-10. (Louvain 1907).

\section{(39) "Memre on the Inhomination [rharistos]" [DH 246]}

Thirteen fragments preserved in multiple anti-Julianist MSS.

(40) "Refutation against the Synod of Chalcedon" [249]

Three fragments preserved in four MSS.

Edited text and English translation of one fragment published in E.A. Wallis Budge, The Discourses of Philoxenos, Bishop of Mabbôgh, A.D. 485-519, vol. 2 (London 1894), xcviii-xcix, xxxiii-xxxvi.

\section{(41) “On Faith" [Fragment] [DH 251]}

Preserved in London, British Library, MS BL Add. 17,206, ff. 30v-33r.

(42) [Fragment without Title, no. 1] [DH 251]

Preserved in London, British Library, MS BL Add. 12,155, f. 161rb.

\section{(43) [Fragment without Title, no. 2] [DH 251]}

Preserved in Birmingham, University of Birmingham, Mingana Collection, MS Syriac 37, f. 4v.

\section{(44) "Letter to Patricius Edessene Monk" [DH 254]}

This work exists in two Syriac recensions (long and short) in multiple MSS and also circulated in a Greek version (of the shorter recension) as a work attributed to Isaac of Nineveh. While the shorter Syriac version has been included in the apparatus of critical editions it remains unpublished as an integral text. ${ }^{21}$

21 Emmanuel Papoutsakis has mentioned that he may prepare an edition. 
Longer version prserved in multiple MS including London, British Library, MS BL Add. 14,649, f. 180r-200v.

Short version preserved only in Vatican City, BAV, MS Vat. Syr. 145r158 r.

Edited text based on edition of Lavenant with Arabic translation

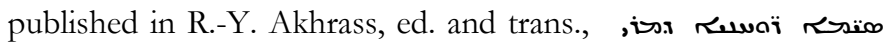

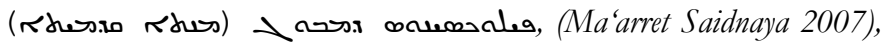
$5-230$.

Edited Syriac text and French translation of longer recension with reference to shorter version published as La lettre à Patricius de Pbiloxène de Mabboug, edited and translated by René Lavenant, PO 30.5 (Paris 1963).

Partial edited Syriac text and Latin translation of longer recension published in M. Kmosko, Liber Graduum, Patrologia Syriaca 3 (Paris, 1926), CCIII-CXXIV.

Partial edited Syriac text and Latin translation of longer recension published in I. Rahmani, Studia Syriaca, vol. 4 (Sharfeh 1909), 70 $73, x_{5}^{-} 5$.

Discussion of the transmission of the Greek text in S.P. Brock, "Syriac into Greek at Mar Saba: The Translation of St. Isaac the Syrian," in J. Patrich, ed., The Sabaite heritage in the Orthodox Church from the Fifth Century to the Present, Orientalia Lovaniensia Analecta 98 (Leuven 2001), 200-208.

Edited Greek text of shorter recension published in N. Theotokou, ed.,

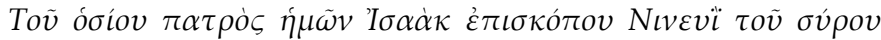

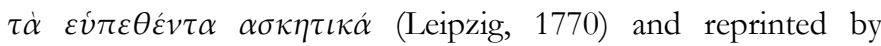
I. Spetsieris (Athens 1895), 366-395.

Edited Greek of shorter recension text published in A. Mai, Nova Patrum Bibliotheca, vol. 8 (Rome 1871), 157-187.

(45) "Letter to Abraham and Orestes, Priests of Edessa, Concerning Stephen Bar Sudaili the Edessene" [DH 259]

Vatican City, BAV, MS Vat. Syr. 103 ff. 60r-63v.

Edited text based on edition of Frothingham with Arabic translation

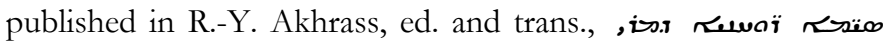

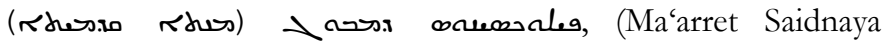
2007), 231-258.

Textual emendations published in T. Jansma, 'Philoxenos' Letter to Abraham and Orestes Concerning Stephen Bar Sudaili: Some 
Proposals with Regard to the Correction of the Syriac Text and the English Translation," Le Muséon 87.1 (1974), 79-86.

Greek translation based on edition of Frothingham published in W. Dommershausen, Pseudo-Hierotheos, Person und Werk. Ein Beitrag zur syrischmystischen, Ph.D. thesis Johannes Gutenberg Universität (Mainz 1949), 255-266.

Edited text and English translation based on MS Vat. Syr. 103 published in A.L. Frothingham, Jr., Stephen Bar Sudaili the Syrian Mystic and the Book of the Hierotheos (Leyden 1886), 28-48.

\section{(46) "Letter to One Newly Converted from the World and Letter to a Disciple" [DH 262]}

This work exists in two variant forms with different titles and closing sections.

Multiple MSS

Edited text based on edition of Olinder with Arabic translation published

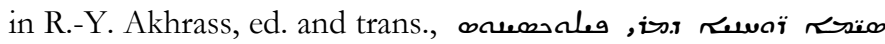

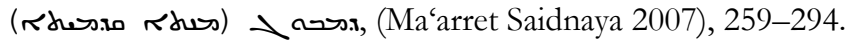

Italian translation published in Filosseno di Mabbug. I sensi dello Spirito: Lettera a un suo discepolo, Lettera parenetica a un ebreo diventato discepolo, translated by S. Chialà, Testi dei Padri della Chiesa 48 (Monastero di Bose 2000).

French translation based on MS BL Add. 12,167 published as "Lettre inédite de Philoxène de Mabboug a l'un de ses disciples," translated by M. Albert, L'Orient syrien, 6 (1961), 243-254.

Edited text and English translation based on MS Vat. Syr. 136, MS BL Add. 14,649, and MS BL Add. 12,167 published as "A Letter of Philoxenos of Mabbug Sent to a Novice," edited and translated by Gunnar Olinder, Göteborgs Högskolas Arsskrift 47 (1942), i-20.

(47) "Letter of Exhortation to One Converted from Judaism" [DH 265]

London, British Library, MS BL Add. 14,726, ff. 10r-11v.

Italian translation of MS BL Add. 14,726 published in Filosseno di Mabbug. I sensi dello Spirito: Lettera a un suo discepolo, Lettera parenetica a un ebreo diventato discepolo, translated by $\mathrm{S}$. Chialà, Testi dei Padri della Chiesa 48 (Monastero di Bose 2000).

French translation of MS BL Add. 14,726 published as "Une Lettre inédite de Philoxène de Mabboug à un juif converti engagé dans la vie monastique," translated by M. Albert, L'Orient Syrien 6 (1961), 41-50. 


\section{(48) "Letter to a Scholasticus Having Become a Monk" [DH 266]}

London, British Library, MS BL Add. 12,167, ff. 278ra-282vb.

French translation published as "Une Lettre inedite de Philoxène de Mabboug à un avocat, devenu moine, tenté par Satan," edited and translated by François Graffin, L'Orient Syrien 5,2 (1960), $183-96$.

\section{(49) "Letter to Recluse Brothers" [DH 267]}

Three fragments in three MS.

\section{(50) [On Prayer] [DH 268]}

Three fragments with attribution but without a title. P. Bettiolo has convincingly demonstrated that the third fragment is actually from John the Solitary. S.P. Brock has suggested that the attribution of the other two fragments to Philoxenos be retained only with a measure of uncertainty.

Three fragments in London, British Library, MS BL Add. 12,167, ff. $182 \mathrm{va}-184 \mathrm{vb}$.

English translation of two fragments published as "Excerpt on Prayer [Nos. 3 and 4]" in The Syriac Fathers on Prayer and the Spiritual Life, translated by Sebastian Brock (Kalamazoo, Mich. 1987), 129_ 131. Syriac version published in S. Brock, Rhï̈rs rinuals rhals sarino (Glane-Losser, Holland 1988) [non vidi].

Edited text and Italian translation of all three fragments published in P. Bettiolo, "Sulla preghiera: Filosseno o Giovanni?" Le Muséon 94 (1981), 75-89.

\section{(51) "Memra on the Faith through Questions" [DH 276]}

Fragments preserved in multiple MSS.

Edited text based on edition of Assemani and Tanghe with Arabic

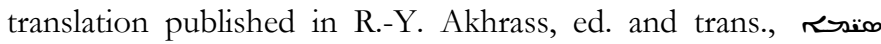

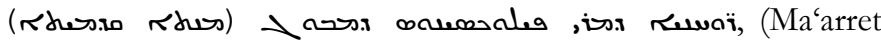
Saidnaya 2007), 295-360.

English translation based on edition of Tanghe published as "On the Indwelling of the Holy Spirit" in The Syriac Fathers on Prayer and the Spiritual Life, translated by Sebastian Brock (Kalamazoo, Mich. 1987), 106-127. Syriac version published in S. Brock, rhals (Glane/Losser 1988), [non vidi]. English translation partially reprinted in S.P. Brock, Spirituality in the Syriac Tradition, $2^{\text {nd }}$ ed. (Kottayam 2005) 129-131. 
Edition and French translation of a fragment from MS BL Add. 17,193 published as "Memra de Philoxène de Mabboug sur l'inhabitation du Saint Esprit," edited and translated by Antoine Tanghe, Le Muséon 73, 3-4 (1960), 39-71.

Partial edition and Latin translation of a fragment from MS Borgia Syr. 10 published in S.-E. and J.-S. Assemani, Bibliothecae apostolicae vaticanae codicum manuscriptorum catalogus, vol. 2 (Rome 1759), 349_ 350.

(52) "On He Who Willingly Transgresses the Prohibition of Priests" [DH 279]

Single fragment preserved in Vatican City, BAV, MS Vat. Syr. 126 f. 391vb-392rc.

\section{(53) “Discourses" [DH 280, cf. 276] $]^{22}$}

This work has the most extensive manuscript tree of any of Philoxenos' works.23 One discourse circulated in Melkite monasteries under the name of Gregory of Nyssa. It also survives in an Arabic version. De Halleux also assigns to the "Discourses" several fragments which Budge has published as fragments of separate works. ${ }^{24}$

Arabic translation published in H. Aho, trans., Tariq al-kamäl / Fïlüksinūs al-Manbaji (Damascus 2008) [non vidi].

Revised French translation published as Philoxène de Mabboug, Homélies, translated by Eugène Lemoine, nouvelle edition revue par René Lavenant, S.J., SC 44 bis (Paris 2007).

Partial Finnish translation published in S. Seppälä, Kerubin silmin. Luostareissa, luolissa, erämaissa ja pylväillä kilvoitelleiden syyrialaisten askeettien bistoriaa (Helsinki 2002), 277-281, 294-295, 296, 300301, 312 [non vidi].

${ }^{22}$ R.A. Kitchen is nearing completion of new English translation of the Discourses.

${ }^{23}$ Readers are refered to de Halleux for the manuscript evidence and also to the discussion of discourse 11 in a palimpsest in S.P. Brock, "Notulae syriacae: Some Miscellaneous Identifications," Le Muséon 108:12 (1995), 69-78.

24 Pinggéra and Kessel mention in their bibliography (vide infra) a vocalized edition based on Budge's edition: K. Budaq, et al., eds, אuiar

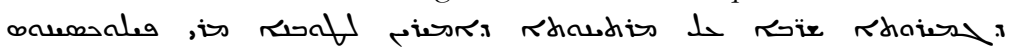

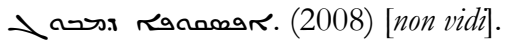


An edition and translation of an abbreviated version of Discourse 9 attributed to Gregory of Nyssa published in M.F.G. Parmentier, "Pseudo-Gregory of Nyssa's Homily on Poverty," $A R A M 5$ (1993), 401-426.

A photostatic reprint of the edition of Budge with Arabic introduction published as Tariq al-kamäl / allafabu bi-al-lughah al-Suryäniayh Fïlüksinūs al-Manbaji (Baghdad 1978) [non vidi].

French translation published as Philoxène de Mabboug, Homélies, translated by Eugène Lemoine, SC 44 (Paris 1956).

Edited text and English translation published as The Discourses of Philoxenos, Bishop of Mabbogh, A.D. 485-519, edited and translated by E.A. Wallis Budge, 2 Vols. (London 1894).

Edited text of Discourses 5 and 10 ("On Simplicity" and "On the Lust of the Belly" published in J.E. Manna, ed., Morceaux choisis de

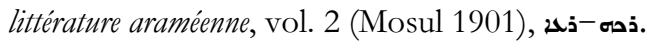

German translation of "On Faith" published in F.W.A. Baethgen, "Philoxenos von Mabug über den Glauben," Zeitschrift für Kirchengeschichte 5.1 (1882), 122-138.

Fragments found in an Arabic manuscript of Der-el-Süryān, are published in Anba Samuel, ed., Al-'äbä’' al-bädiqün fì l-'íbäda, vol. 1, (Egypt, $\left.1951^{1} / 1972^{2} / 2005^{3}\right)$ [non vidi].

Cf. the following review articles:

R.A. Kitchen, review of Lemoine, E. and Lavenant, R., trans., Pbiloxène de Mabboug. Homélies (1956 and 2007), Hugoye 13:1 (2010), 65-73.

T. Jansma, review of E. Lemoine, trans., Pbiloxène de Mabboug. Homélies (1956), Vigiliae Christianae 12:4 (1958), 233-237.

I. Hausherr, "Spiritualité syrienne: Philoxène de Mabboug en version française," Orientalia Christiana Periodica 23.1 (1957), 171-185.

(54) "Familiar Mamlla to the Brothers Concerning Stillness which is in the Service and Order of the Monastery" [DH 288-90]

Fragments preserved in multiple MSS.

Edition and French translation published C. Moulin Paliard, Un Mamllo sur le recueillement inédit du VIT siècle, Diplôme l'École Pratique des Hautes Études Sciences Réligieuses, Paris, 2005 [non vidi].

(55) [Fragments on Prayer Humility and Penance] [DH 288290]

Two fragments preserved in multiple MSS. 
Edition of one fragment from on MS BL Add. 14,582 published in

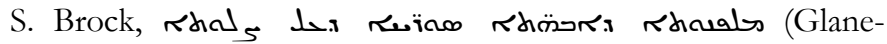
Losser, Holland 1988), 80 [non vid]].

English translation of one fragment from MS BL Add. 14,582 published as "Excerpt on Prayer" in The Syriac Fathers on Prayer and the Spiritual Life, translated by Sebastian Brock (Kalamazoo, Mich. 1987), 128.

\section{(56) "On the Council of Chalcedon" [no reference in DH]}

Two fragments preserved in two MSS. One fragment in Cambridge, Mass. Harvard University, Houghton Library, MS Syriac 38, ff. 111v121v remains unpublished.

French translation in A. de Halleux, "Un fragment philoxénien inédit de polémique anti-chalcédonienne," in W.C. Delsman et al., eds., Von Kanaan bis Kerala: Festschrift für Prof. Mag. Dr. J.P.M. van der Ploeg O.P. zur Vollendung des siebrigsten Lebensjahres am 4. Juli 1979 überreicht von Kollegen, Freunden und Scbülern (Neukirchen-Vluyn 1982), 431-441.

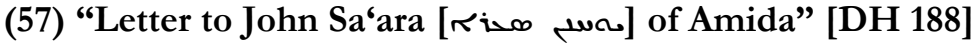

Brief quotations preserved in the vita by Elia of Qartamin (vita "b" supra) and the anonymous "Victory of Mar Aksnoyo" (see above).

Cf. A. de Halleux, ed., Éli de Qartmin: Memra sur S. Mar Pbiloxène de Mabbog, CSCO 100-101 (Louvain 1963), textus 9-10.

Cf. S.P. Brock, "Tash'ita de-Mar Aksnaya," Qolo Suryoyo 110 (July/Aug 1996), 246.

\section{B. LOST WORKS}

\section{(58) [Letter to the Isaurian Bishops Rejecting Strictness (rhadudw)] [DH 188]}

Severus of Antioch, in a letter to the presbyters at Alexandria (no. 39) mentions that Philoxenos had written to the Isaurian bishops rejecting their demands for purging the names of heretics from the diptychs.

Cf. Severus of Antioch, A Collection of Letters of Severus of Antioch: From Numerous Syriac Manuscripts, edited and translated by E.W. Brooks, Patrologia Orientalis 12 (Paris 1919), 296. 


\section{(59) "Letter to Beronikios [كسنصن], Abbot of Beth Mar Hanina" [DH 188]}

The chronicle of Pseudo-Zacharias mentions that Philoxenos wrote from exile to a certain Beronikios, Abbot of Beth Mar Hanina.

Cf. E.W. Brooks, Historia ecclesiastica Zachariae rhetori vulgo adscripta, CSCO 84 and 88 (Louvain 1921 and 1953), 81, 56.

Cf. S.P. Brock, "St Aninas/Mar Hanina and his monastery," Analecta Bollandiana 124 (2006), 5-10 [non-vidi].

\section{(60) [Earlier Letter to the Monks of Beth Gogal] [DH 188]}

In his Second Letter to the Monks of Beth Gogal (no. 22 supra), Philoxenos refers to an earlier letter which he wrote to them. Based on Philoxenos' description, De Halleux concluded that this earlier letter is separate from the other extant letter to the monks of Beth Gogal (First Letter to the Monks of Beth Gogal, no. 21 supra). This third or "earlier" letter is now lost.

Cf. A. de Halleux, "La deuxième lettre de Philoxène aux monastères du Beit Gaugal," edited and translated by André de Halleux, Le Muséon 96, 3-4 (1983), 9-10, 28-29.

(61) "Letter to Eustorgius [oneinfor]" [DH 253]

Mentioned as a work of Philoxenos in the life of Simeon of Qartamin.

Cf. F. Nau, "Notice historique sur le monastère de Qartàmin" in Actes du XIV Congrès international des Orientalistes, vol. 2 (Paris 1906), 45, 83.

(62) [Letters to the Sons of Gurzan [ [-1in] and the People of Inner Persia] [no reference in DH].

Mentioned as a work or works of Philoxenos in the "Victory of Mar Aksnoyo" (see above).

Cf. S.P. Brock, "Tash'ita de-Mar Aksnaya," Qolo Suryoyo 110 (July/Aug 1996), 246.

Cf. I.A. Barsoum, The Scattered Pearls: The History of Syriac Literature and Sciences, $2^{\text {nd }}$ Rev. Ed. (Piscataway, N.J. 2003), 268. 


\section{Dubious AND SPURIOUS WORKS}

\section{$\left(63^{*}\right)$ [Iconoclastic Fragments] [DH 88]}

At the Second Council of Nicaea in 787, Philoxenos and Severus of Antioch were charged as iconoclasts on the testimony of various church historians. De Halleux strongly rejected the validity of this charge on several grounds: the lack of such sentiments in Philoxenos' extant works, the prejudice of the council against miaphysites, and the fact that all of the testimonies were ultimately reliant on the now lost work of Theodore Lector. De Halleux preferred to instead attribute Philoxenos' opposition to the use of dove imagery as part of an effort to avoid syncretism with the worship of Atargatis in Syria. While admitting that the evidence from the council is suspect, Glenn Peers has subsequently argued for a more nuanced reading of Philoxenos's Christology as having a "fundamental suspicion of images." For further literature see: G. Peers, Subtle Bodies: Representing Angels in Byzantium (Berkeley 2001), $71 \mathrm{ff}$.

Two of the fragments charging iconoclasm are translated in C. Mango, The Art of the Byzantine Empire 312-1453 (Toronto 1986), 43-44.

(64*) "Memra of Faith Concerning that Simon [Peter] Said Jesus of Nazareth was a Man from God. Spoken against Those Who Think that Jesus and Christ are the Names of a Man Who Came Down from God and Do Not Think that God Became Man" [DH 162]

A fragment of this work is reported by Assemani, Bibliotheca Orientalis. vol. 2 (Rome, 1721), 45 as being preserved on a now illegible folio of MS Vat. Syr 136. De Halleux has questioned whether it should be viewed as a separate work due to lack of manuscript evidence other than Assemani. De Halleux suggests it may have been a fragment of the Memra Against Habib.

(65*) "Disputation with One of the Learned Nestorians Concerning the Fact that the God of Our Lord Jesus Christ is the Father of Glory" [DH 163]

De Halleux questioned the authenticity of this short work on the grounds of genre and style and the anti-Julianist learnings of the text. If these elements are Philoxenian, he suggests that at the least they have been redacted.

Vatican City, BAV, MS Vat. Syr. 135 ff. 71va-77rb. 


\section{(66*) "Natural [حس ] Disputation of Nestorians and Orthodox" [DH 164]}

This anonymous work is not attributed to Philoxenos but is preserved in a manuscript composed primarily of Philoxenian texts. Vatican City, BAV, MS Vat. Syr. 135 ff. 77rb-80va.

\section{(67*) "A Dialogue between the Church and Nestorius" [DH 165]}

This acephalous and fragmentary text is attributed to Philoxenos but its inconsistencies with the rest of Philoxenos' works have been noted by de Halleux.

London, British Library, MS BL Add. 14,534, ff. 9-20.

\section{$\left(68^{*}\right)$ "We believe in the Confession of One True God" [DH 177]}

De Halleux noted that the wide variation and anachronisms in the versions of this text indicate that it cannot be strictly attributed to Philoxenos at least in the extant versions.

Preserved in multiple MSS and recensions.

Edited text and English translation based on a Mor Gabriel MS in Edip Aydin, The Christological Thought of Pbiloxenos of Mabbug in Reaction to the Council of Chalcedon (London: Bachelor of Divinity Thesis, Heythrop College, University of London, 1995), 11-13.

\section{(69*) “[Lost] Letter to Himyarites” [DH 188]}

The anonymous "Victory of Mar Aksnoyo" (see above) attributes a letter to the Himyarites to Philoxenos. De Halleux rightly points out that this is mostly likely a reference to a letter of Simeon of Beth Arsham. Barsoum's description of the letter as "a letter to the Himyarite Christians during the adversity inflicted on them by Masruq the Jewish King because of their Christianity" fits this interpretation of de Halleux. Nevertheless, since no such letter is extant no futher conclusions can be drawn. Philoxenos did, however, ordain the first two bishops of Najran, however, so the existence of a letter to the Himyarites which may have been confused with the later letter of Simeon is possible.

Cf. S.P. Brock, "Tash'ita de-Mar Aksnaya," Qolo Suryoyo 110 (July/Aug 1996), 246.

Cf. I. Shahid, The Martyrs of Najran: New Documents, Subsidia Hagiographica (Bruxelles 1971), 238, 271, et passim. 
Cf. I.A. Barsoum, The Scattered Pearls: The History of Syriac Literature and Sciences, $2^{\text {nd }}$ Rev. Ed. (Piscataway, N.J. 2003), 269.

\section{$\left(70^{*}\right)$ [On the Turks] [DH 203]}

In the Letter to Abu Ya'fur (no. 23 supra), an interpolated section on the Turks has been attributed to Philoxenos. See discussion above.

\section{(71*) “Memra against Nestorians and Eutychians" [DH 224]}

A fragment of this work is reported by Assemani, Bibliotheca Orientalis, vol. 2 (Rome, 1721), 45 as being preserved on a now illegible folio of MS Vat. Syr 136. De Halleux has questioned whether it should be viewed as a separated work due to lack of manuscript evidence other than Assemani. De Halleux suggests it may have been a fragment of the Book of Sentences.

\section{(72*) "Letter Sent to a Friend...Concerning the Three Steps" [DH 269]}

This work is repeatedly attributed to Philoxenos in the manuscript tradition. A small fragment also circulated as a prayer attributed to Philoxenos (see $78 j^{*}$ below). In the last half century, however, scholars-led by Paul Harb-have increasingly questioned its authorship. It has now been firmly determined to be the work of Joseph of Hazzaya. While the text has become central to the study of Joseph it did not play a similar position in modern scholarship on Philoxenos and thus the reassignment of authorship has not significantly affected existing interpretations of Philoxenos' theology. Moreover, many of the Evagrian themes of the letter have parallels in the authentic works of Philoxenos. Nevertheless, it should be noted that works before the 1960s will usually have taken this work to be Philoxenian.

Relevant information on history of interpretation of the text and a critical edition with French translation is published as Joseph Hazzaya, Lettre sur les trois étapes de la vie monastique, eds. P. Harb and F. Graffin, PO 45.2 (Brepols, 1992).

A significant article on the attribution is P. Harb, "Faut-il restituer à Joseph Hazzaya la Lettre sur les trois degres de la vie monastique attribuée à Philoxène de Mabboug?” Melto 4.2 (1968), 13-36.

A French translation, apparently independent of the previous edition of Olinder, published as "La Lettre de Philoxène de Mabboug à un 
supérieur de monstère sur la vie monastique," translated by F. Graffin, L'Orient Syrien 6.1-2 (1961), 317-352, 455-486.

A facsimile edition based on MS BL Add. 17,262 and collated with two other MSS is published as "A Letter of Philoxenos of Mabbug Sent to a Friend," edited and translated by G. Olinder in Acta Universitas Gotoborgensis, Göteborgs Högskolas Arsskrift, vol. LVI (1950), i-63.

\section{(73*) "Exhortation of Mar Philoxenos" [DH 275]}

De Halleux has identified that this work is actually letter no. 28 in the letters of Jacob of Sarug. Cf. G. Olinder, ed. Iacobi Sarugensis epistulae quotquot supersunt, CSCO 110 (Louvain 1937), 229.

London, British Library, MS BL Add. 17,206, ff. 54r-59r.

\section{(74*) [Works of Pseudo-Nilus] [DH 275]}

Although no examples are extant which pseudonymously substitute Philoxenos as the author of the works of Pseudo-Nilus, de Halleux has identified at least two scribal notes which suggest that this may have been the view of some medieval readers.

\section{(75*) [Fragments on Virgins and Tonsure] [DH 290]}

De Halleux notes that these fragments are too short to be authenticated.

London, British Library, MS BL Add. 14,613, f. 141v.

London, British Library, MS BL Add. 17,193, f. 83v.

London, British Library, MS BL Add. 17,215, f. 43r.

\section{(76*) “Concerning a Departed Brother" [DH 290]}

Attributed to Philoxenos but attested only in one manuscript and considered among the dubia by de Halleux on stylistic grounds.

London, British Library, MS BL Add. 14,520, ff. 123v-125r.

(77*) "Commentary of Filekseyus"or "Commentary on the Paradise of the Fathers" [DH 291]

Philoxenos is commemorated in the Ethiopian Church as one of three ascetic doctors. The work which circulated widely in Ge'ez under the name of Filekseyus is actually Dadisho Qatraya's commentary on Palladius. For further information see W. Witakowski "Filekseyus, the Ethiopic version of the Syriac Dadisho Qatraya's Commentary on the Paradise of the Fathers," Rocznile Orientalistyczny, 59:1 (2006), 281-296. 


\section{(78*) Prayers [DH 293-302]}

A substantial amount of liturgical material is attributed to Philoxenos. Many of these items do not yet have a critical edition and this is an area wide open for further scholarship. The general consensus from de Halleux to the present is that these works are generally later than Philoxenos, a conclusion supported by the date of the extant copies and the fact that some of the same items can be found attributed to other authors. De Halleux concludes that while some may be drawing on Philoxenian phrases and themes, the evidence has been so heavily redacted that authentication of Philoxenian elements is no longer possible. As indicated above, a comprehensive clavis to the liturgical works of Philoxenos cannot be written until further manuscript research has been done. At present, Roger Akhrass is beginning to collect and edit these texts. Further work in this area is the greatest desiderata with regard to unedited material in the Philoxenian and Pseudo-Philoxenian corpus. Several of prayers attributed to Philoxenos have been

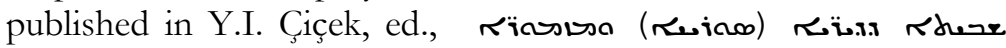

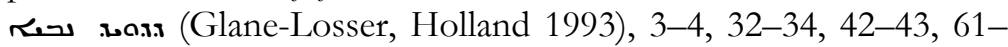
64, 80-81, 104-118, 134-135 [non vidi] and reprinted with an

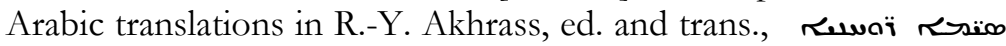
(x), (Ma'arret Saidnaya 2007). See below for individual items. ${ }^{25}$

(78a*) "To you I pray at this time in fear..." [Eucharistic Prayer I] [DH 295]

London, British Library, MS BL Add. 17,125, f. 78r.

(78b*) “I carry you, living God...” [Eucharistic Prayer II] [DH 295]

London, British Library, MS BL Add. 14,529, f. 16v-17r.

London, British Library, MS BL Add. 17,125, f. 78r.

An edition and English translation published as A. Cody, "An Instruction of Philoxenos of Mabbug on Gestures and Prayer when One Receives Communion in the Hand, with a History of the Manner of Receiving the Eucharistic Bread in the West Syrian

${ }^{25} \mathrm{I}$ am grateful to Roger Akhrass who assisted me in preparing this section including improving my translations of the titles and who, along with Sebastian Brock, provided citations for the texts published by Çiçek to which I did not have access. 
Church,” in N. Mitchell and J.F. Baldovin, eds., Rule of Prayer, Rule of Faith: Essays in Honor of Aidan Kavanagh, O.S.B. (Collegeville, Minnesota 1996), 56-79.

\section{(78c*) “Great love unceasing...” [Penitential Prayer] [DH 296]}

De Halleux notes three passages in this prayer which are taken verbatim from the Discourses.

Multiple MSS, but most completely in London, British Library, MS BL Add. 14,621, f. 160vb-164rb.

\section{(78d*) “Glorious name that sanctifies..." [DH 298]}

De Halleux notes that this prayer is preserved as part of the Syrian Orthodox breviary.

Multiple MSS.

Edition based on the edition of Çiçek with Arabic translation published in

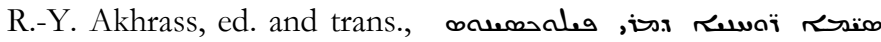

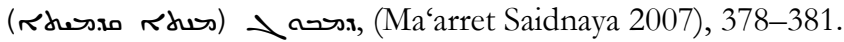

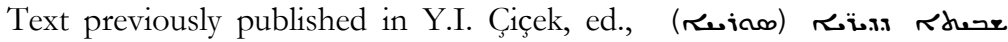
(Glane-Losser, Holland 1993), 61-64 [non vidi].

\section{(78e*) “Glory to you, God..." [DH 299]}

De Halleux notes that this prayer is the best preserved prayer attributed to Philoxenos, surviving in multiple MSS as part of the Syrian Orthodox breviary and also preserved in Arabic and Ethiopic.

Multiple MSS.

Edition based on the edition of Çiçek with Arabic translation published in

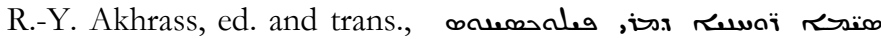
(Macherret Saidnaya 2007), 382-391.

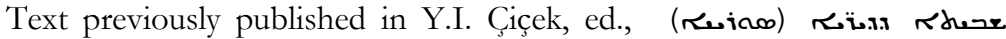
19:118 [non vidi].

(78**) "I give thanks to you, God..." [DH 301]

Multiple MSS.

Edition based on the edition of Çiçek with Arabic translation published in

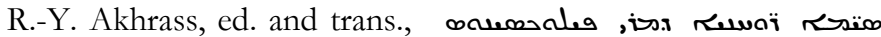

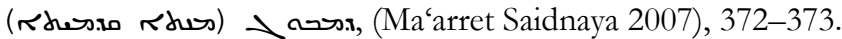

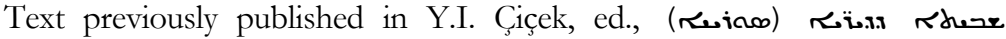
. 
(78g*) "Watcher who does not slumber or sleep..." [DH 301] Multiple MSS.

Edition based on the edition of Çiçek with Arabic translation published in

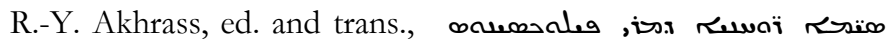

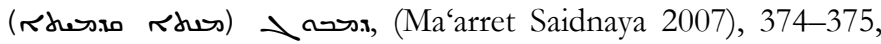
380-381.

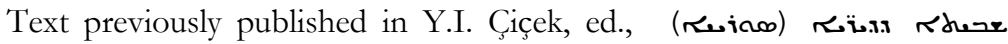
(Glane-Losser, Holland 1993), 32-24, 8081 [non vidi].

\section{(78h*) "I beg your holy name..." [no reference in DH]}

Edition based on the edition of Çiçek with Arabic translation published in

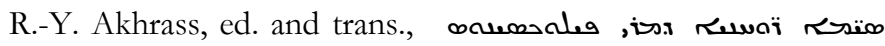

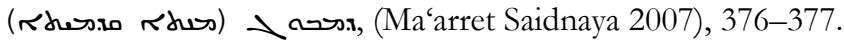

Text previously published in Y.I. Çiçek, ed., (ארe (Glane-Losser, Holland 1993), 42-43 [non vidi].

(78i*) "Yea Lord my savior and my life-giver I ask..." [no reference in $\mathrm{DH}$ ]

Edition based on the edition of Çiçek with Arabic translation published in

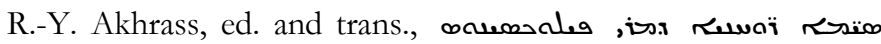

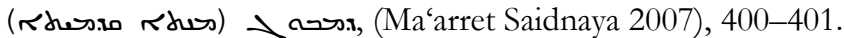

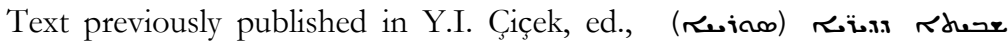

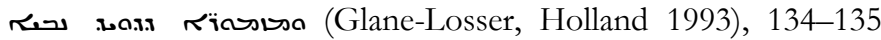
[non vidi].

$\left(78 j^{*}\right)$ "God make me worthy, that my mind may rejoice..." [Prayer before the Gospel] [DH 272]

This text is actually an excerpt taken from Joseph Hazzayas' "Letter Sent to a Friend...Concerning the Three Steps" a text noted above (see no. $72^{*}$ ) to often have been attributed to Philoxenos.

Birmingham, University of Birmingham, Mingana Collection, MS Syriac 480 , ff. $15 \mathrm{v}$.

Vatican City, BAV, MS Vat. Syr. 58 f. 72r-v.

Edition based on the published editions of the "Letter Sent to a Friend... Concerning the Three Steps" (listed under $72^{*}$ above) with Arabic translation published in R.-Y. Akhrass, ed. and trans.,

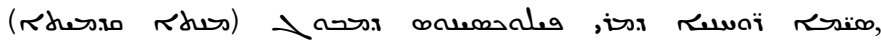
(Ma'arret Saidnaya 2007), 402-403. 


\section{(79*) Ma'nitha on the Nativity of Our Lord [No Reference in DH]}

Mentioned without citation in I.A. Barsoum, The Scattered Pearls: The History of Syriac Literature and Sciences, $2^{\text {nd }}$ Rev. Ed. (Piscataway, N.J. 2003), 266.

\section{(80*) Short Baptismal Ordo [DH 303]}

Edited text of an order of baptism based on edition of Assemani and additional manuscripts with Arabic translation published in R.-Y. Akhrass, ed. and trans., orworale

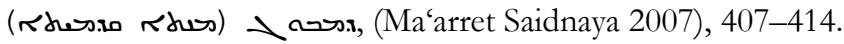

The epiklesis is published based on the edition of Assemani in S.P. Brock, "The Epiklesis in the Antiochene Baptismal Ordines," Orientalia Christiana Analecta 197 (1974), 183-218.

Edited text of an order of baptism with and Latin translation published in J.A. Assemani, Codex liturgicus ecclesiae universae, vol. 2 (Rome 1749), 307-309 and reprinted in H. Denzinger, Ritus orientalium, vol. 1 (Wurzburg 1863), 318.

\section{(81*) Anaphorae [DH 305]}

Three anaphorae are attributed to Philoxenos (enumerated I, II, and III here). Only Anaphora I has been published in Syriac.

A. Raes provides manuscript details in A. Raes, ed., Anaphorae syriacae, I.i (Rome 1939), v-xlix and idem, Introductio in liturgiam orientalem (Rome 1947) [non vidi].

Cf. I.A. Barsoum, The Scattered Pearls: The History of Syriac Literature and Sciences, $2^{\text {nd }}$ Rev. Ed. (Piscataway, N.J. 2003), 266.

Edited text of Anaphora I based on the edition of Çiçek and Yeshu' with Arabic translation published in R.-Y. Akhrass, ed. and trans.,

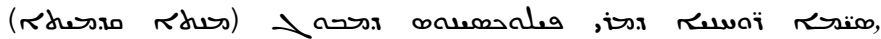
(Ma'arret Saidnaya 2007), 415-448.

Edited text of Anaphora I based on edition of Çiçek with English translation published in A.Y. Samuel, ed., Anaphoras: The Book of the Divine Liturgies (Teaneck/Lodi, N.J. 1991), 383-406 [non vidi]. The English translation is also online: http:// sor.cua.edu/Liturgy/Anaphora/Philoxenos.html. 
Edited text of Anaphora I is published in Y.I. Çiçek, wor ringrur

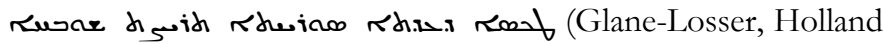
1985), 169-182 [non vidi]. ${ }^{26}$

Edited text of Anaphora I is published (with attribution to Basil) in Missale syriacum juxta ritum ecclesiae antiochenae syrorum (Rome 1847), - مدm זمo.

Latin translation of Anaphora I and II is published in E. Renaudot, Liturgiarum orientalium collectio, vol. 2, $2^{\text {nd }}$ ed. (Paris 1847), 300319.

\section{$(82 *)$ [On the Eight Sleepers of Ephesus] [no reference in $\mathrm{DH}]$}

J.E. Manna attributed to Philoxenos a text without provenance on the eight sleepers of Ephesus in in J.E. Manna, ed., Morceaux choisis de

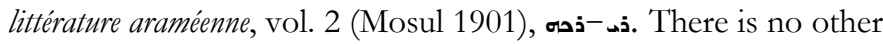
extant reference to such a text by Philoxenos. This text is a misattribution by Manna who apparently took the text from I. Guidi, Testi orientali inediti sopra i Sette dormienti di Efeso (Roma 1885), 34-44. Guidi's text is that of London, British Library, MS BL Add. 12,160 ff. 147r-153r. Neither Guidi nor the MS attribute the text to Philoxenos. ${ }^{27}$

\section{(83*) [Arabic Scholion to Genesis 9:18-21] [DH 126]}

See the discussion of this scholion in the same issue of Hugoye as this clavis. McCollum concludes that the scholion is not likely to be Philoxenian based on style.

A. McCollum, "An Arabic Scholion to Genesis 9:18-21 (Noah's Drunkenness) Attributed to Philoxenos of Mabbug," Hugoye 13:2 (2010), 7-30.

${ }^{26}$ This same text may also be in Y.I. Çiçek, ed., Ringrurs rads (ruiah ruil ruino) (Glane-Losser, Holland 1985) [non vidi], but a copy was not accessible for consultation.

${ }^{27}$ I am grateful to Sebastian Brock for working out this provenance. 


\section{STUDIES AND MENTION IN SELECTEd GENERAL WORKS}

\section{A. Monographs with extended treatment of Philoxenos ${ }^{28}$}

J. Lebon, Le Monophysisme sévérien: Étude historique, littéraire et théologique sur la résistance monophysite au Concile de Chalcédoine jusqu'à la constitution de l'Église jacobite (Louvain 1909).

G. Zuntz, The Ancestry of the Harklean New Testament, British Academy Supplemental Papers (London 1945).

A. Vööbus, Studies in the History of the Gospel Text in Syriac, CSCO Subsidia (Louvain 1951).

- Early Versions of the New Testament, Manuscripts Studies (Stockholm, 1954).

A. Guillaumont, Les 'Kephalaia Gnostica' d'Évagre le Pontique et l'bistoire de l'origénisme chez les Grecs et chez les Syriens' (Paris 1962).

A. de Halleux, Philoxène de Mabbog: Sa vie, ses écrits, sa theologie (Louvain 1963).

I. Yacoub III, Mysteries in the struggle of Saint Pbiloxenos of Mabboug (Damascus 1970) [in Arabic, non vidi].

W. Strothmann, Johannes von Apamea (Berlin 1972).

R.C. Chesnut, Three Monophysite Christologies: Severus of Antioch, Pbiloxenos of Mabbug, and Jacob of Sarug (Oxford 1976).

D.J. Fox, The "Matthew-Luke Commentary" of Philoxenos: Text, Translation, and Critical Analysis (Missoula, Mont. 1979).

J. Martikainen, Gerechtigkeit und Güte Gottes: Studien zur Theologie von Ephraem dem Syrer und Pbiloxenos von Mabbug (Wiesbaden 1981).

G. Lardreau, Discours philosophique et discours spirituel: autour de la philosophie spirituelle de Pbiloxène de Mabbong (Paris 1985).

S.P. Brock and M.A. Mathai, Pbiloxenos of Mabbug, Seeri Correspondence Course on Syrian Christian Heritage (Kottayam, India 1989).

R.J.V. Hiebert, The "Syrohexaplaric"Psalter (Atlanta 1989).

R.G. Jenkins, The Old Testament Quotations of Philoxenos of Mabbug, CSCO Subsidia (Louvain, 1989).

${ }^{28}$ The following monographs have been included because they make significant mention of Philoxenos. As the decision as to what constitutes a "significant" reference to Philoxenos is subjective, I have erred on the side of inclusion so the reference to Philoxenos in some of the works below may not be central to the main themes of the work in question. 
Anba Bishoy, Saint Philoxenos bishop of Mabboug, His biography, Sayings and Writings, (Egypt, 1999) [in Arabic, non vidi].

J. Hatem, La Gloire de l'Un: Philoxène de Mabboug et Laurent de la Résurrection (Paris 2003).

D. King, The Syriac Versions of the Writings of Cyril of Alexandria: A Study in Translation Technique (Leuven 2008).

F. Alpi, La route royale: Sévère d'Antioche et les églises d'Orient (512-518), 2 vols. (Beyrouth, 2009).

\section{B. Monographs with mention of Philoxenos}

J.B. Chabot, De S. Isaaci Ninivitae vita, scriptis et doctrina (Paris 1892).

J. Gwynn, The Apocalypse of St. John, in a Syriac version bitherto unknown (Dublin 1897).

. Remnants of the Later Syriac Versions of the Bible, 2 vols. (London 1909)

De L. O'Leary, The Syriac Church and Fathers (London 1909).

W.A. Wigram, The Separation of the Monophysites (London 1923).

R. Draguet, Julien d'Halicarnasse et sa controverse avec Sévère d'Antioche sur l'incorruptibilité du corps du Christ. Études d'bistoire littéraire et doctrinale, suivie des fragments dogmatiques de Julien (Louvain 1924).

P. Charanis, The Religious Policy of Anastasius I: Emperor of the Later Roman Empire, 491-518 (Madison, Wisc. 1935).

W. de Vries S.J., Sakramententheologie bei den syrischen Monophysiten (Rome 1940).

R. Devreesse, Le Patriarcat d'Antioche; Depuis la paix de l'Eglise jusqu' à la conquête arabe (Paris 1945).

F.S. Marsh, The Book of the Holy Hierotheos Ascribed to Stephen Bar-Sudhaile (c500 A.D.) with Extracts from the Prolegomena and Commentary of Theodosios of Antioch and From the "Book of Excerpts" and Other Works of Gregory Bar-Hebraeus (London 1949).

E. Stein, Histoire du Bas-Empire. Tome II: De la disparition de l'empire de l'occident à la mort de Justinien (467-565) (Paris 1949).

E. Honigmann, Évêques et évêchés monophysites d'Asie antérieure au VT siècle, CSCO Subsidia (Louvain 1951).

W. de Vries S.J., Der Kirchenbegriff der von Rom getrennten Syrer (Rome 1955) [non vidi].

A. Vööbus, History of Asceticism in the Syrian Orient: A Contribution to the History of Culture in the Near East, 3 vols., CSCO Subsidia (Louvain 1958). 
I. Hausherr, Hésychasme et prière, Orientalia Christiana Analecta 176 (Rome 1966) [non vidi].

I. Shahid, The Martyrs of Najran: New Documents, Subsidia Hagiographica (Bruxelles 1971)

E.P. Siman, L'Expérience de l'esprit par l'Église d'après la traditionne syrienne d'Antioche (Paris 1971).

W. H. C. Frend, The Rise of the Monophysite Movement: Chapters in the History of the Church in the Fifth and Sixth Centuries (Cambridge 1972).

J. Meyendorff, Christ in Eastern Christian Thought (Crestwood, N.Y. 1975).

B.M. Metzger, The Early Versions of the New Testament: Their Origin, Transmission, and Limitations (Oxford 1977).

P.T.R. Gray, The defense of Chalcedon in the East (451-553) (Leiden 1979).

E. Klum-Böhmer, Das Trishagion als Versöbnungsformel der Christenheit: Kontroverstheologie im V. und VI. Jabrbundert (München 1979).

L. Sako, Le rôle de la biérarchie syriaque orientale dans les rapports diplomatiques entre la perse et Byzance aux $V^{2}-V I I^{e}$ siècles (Paris, 1986).

G. Florovsky, The Byzantine Fathers of the Sixth to Eighth Century (Vaduz 1987).

P. Brown, The Body and Society: Men, Women, and Sexual Renunciation in Early Christianity (New York 1988).

S.P. Brock, Spirituality in the Syriac Tradition, $1^{\text {st }}$ ed. (Kottayam, India 1989). . The Bible in the Syriac tradition, $1^{\text {st }}$ ed. (Kottayam, India 1989).

J. Meyendorff, Imperial Unity and Christian Divisions: The Church, 450680 A.D. (Crestwood, N.Y. 1989).

I. Shahid, Byzantium and the Arabs in the Fifth Century (Washington, D.C. 1989).

B. Varghese, Les Onctions baptismales dans la tradition syrienne, CSCO Subsidia (Louvain 1989).

A. Palmer, Monk and Mason on the Tigris Frontier: The Early History of Tur Abdin (Cambridge 1990).

B. Daley, The Hope of the Early Church: A Handbook of Patristic Eschatology (Cambridge 1991).

C. Stewart, 'Working the Earth of the Heart': The Messalian Controversy in History, Texts, and Language to AD 431 (Oxford 1991).

T. Merton and L. Cunningham, Thomas Merton, Spiritual Master: The Essential Writings (New York 1992).

S.H. Moffett, A History of Christianity in Asia: Beginnings to 1500 ([San Francisco] 1992). 
K. McDonnell and G.T. Montague, Christian Initiation and Baptism in the Holy Spirit: Evidence from the First Eight Centuries, $2^{\text {nd }}$ edition (Collegeville, Minnesota 1994).

S.P. Brock, The Holy Spirit in the Syrian Baptismal Tradition, 2nd ed. (Pune, India 1998).

K. Fitschen, Messalianismus und Antimessalianismus. Ein Beispiel ostkirchlicher Ketzergeschichte (Göttingen, 1998).

H. O. Old, The Reading and Preaching of the Scriptures in the Worship of the Christian Church: Volume 2, The Patristic Age (Grand Rapids, Mich. 1998).

P. Escolan, Monachisme et Église. Le monachisme syrien du $I V^{e}$ au $V I I^{e}$ siècle (Paris 1999).

T. Kollamparampil, Salvation in Christ According to Jacob of Serugh (Bangalore 2001).

M.J. Panicker, The Person of Jesus Christ in the Writings of Juhanon Gregorius Abu'l Faraj Commonly called Bar Ebraya (Münster, 2002).

K. Pinggéra, All-Erlösung und All-Einheit. Studien zum Buch des heiligen Hierotheos' und seiner Rezeption in der syrisch-orthodoxen Theologie (Würzburg, 2002) [non-vidi].

J.-E. Steppa, John Rufus and the World Vision of Anti-Chalcedonian Culture, Gorgias Dissertations (Piscataway 2002).

E. Kaniyamparampil, The Spirit of Life: A Study of the Holy Spirit in the Early Syriac Tradition (Kottayam, India 2003).

C.A. Karim, Symbols of the Cross in the Writings of the Early Syriac Fathers (Piscataway N.J, 2004).

S.P. Brock, Spirituality in the Syriac Tradition, $2^{\text {nd }}$ ed. (Kottayam, India 2005).

A.H. Becker, Fear of God and the Beginning of Wisdom: The School of Nisibis and Christian Scholastic Culture in Late Antique Mesopotamia (Philadelphia 2006).

P. Blaudeau, Alexandrie et Constantinople, 451-491: De l'bistoire à la géoecclésiologie (Rome 2006).

S.P. Brock, The Bible in the Syriac Tradition, $2^{\text {nd }}$ ed. (Piscataway, N.J. 2006).

F.K. Harrer, Anastasius I: Politics and Empire in the Late Roman World (Cambridge 2006).

C.B. Horn, Asceticism and Christological Controversy in Fifth-Century Palestine: The Career of Peter the Iberian (Oxford 2006).

T. Merton, Pre-Benedictine Monasticism: Initiation into the Monastic Tradition 2 (Kalamazoo, Mich. 2006).

S.P. Brock, Studies in Syriac Spirituality (Bangalore 2008). 
B. Colless, The Wisdom of the Pearlers: An Anthology of Syriac Christian Mysticism (Kalamazoo, Mich. 2008).

V. Menze, Justinian and the Making of the Syrian Orthodox Church (Oxford, 2008).

V. Menze and K. Akalin, John of Tella's "Profession of Faith" (Piscataway, N.J. 2009).

\section{Unpublished dissertations and theses ${ }^{29}$}

E. Bergsträsser, Monophysitismus und Paulustradition bei Pbiloxenos von Mabbug, Th.D. dissertation, Universität Erlangen-Nürnberg, 1953.

P. Harb, La vie spirituelle selon Pbiloxène de Mabbug, Ph.D. dissertation, L’Université de Strasbourg, 1968.

R.A. Kitchen, The Just and Perfect in the Ascetical Homilies of Pbiloxenos of Mabbug and the Liber Graduum, M.A. thesis, The Catholic University of America, 1978.

M. Mattathil, The Christology of Philoxenos of Mabbug Mainly Based on His Ten Discourses against Habib, Ph.D. thesis, Pontifical Oriental Institute 1984.

E. Sleman, Devenir de Dieu et devenir des hommes selon Philoxène de Mabboug, Mémoire de maîtrise en Théologie, Institut catholique de Paris, 1988 [non vidi].

E.[H.E. Mor Polycarpus] Aydin, The Christological Thought of Philoxenos of Mabbug in Reaction to the Council of Chalcedon, Bachelor of Divinty thesis, Heythrop College, University of London, 1995.

R.A. Kitchen, The Development of the Status of Perfection in Early Syriac Asceticism, with Special Reference to the Liber Graduum and Pbiloxenos of Mabbug, D.Phil. thesis, Oxford University, 1997.

A.-M. Saadi, Moshe bar Kepha's Commentary on Luke: A Ninth Century Apology, Ph.D. dissertation, Lutheran School of Theology at Chicago, 1999.

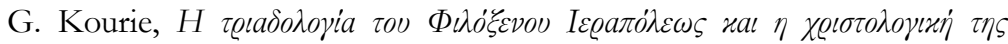

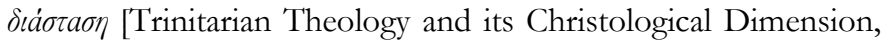
according to Philoxenos of Mabboug], master's thesis, Aristotle University of Thessaloniki, 2005 [non vidi].

${ }^{29}$ Dissertations or theses that have subsequently been published as monographs have been excluded since the monographs are cited in the preceding section. 
C. Moulin Paliard, Un Mamllo sur recueillement inédit du VI $T^{e}$ sciècle, Diplôme de l'Ecole Pratique des Hautes Etudes Sciences Réligieuses, Paris, 2005.

D.A. Michelson, Practice Leads to Theory: Orthodoxy and the Spiritual Struggle in the World of Philoxenos of Mabbug (470-523), Ph.D. dissertation, Princeton University, 2007.

M. Dickens, Turkeaye: Turkic Peoples in Syriac Literature prior to the Seljüks, $\mathrm{PhD}$ thesis, University of Cambridge, 2008.

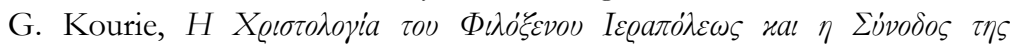
Xaגxinóvas [The Christology of Philoxenos of Mabboug and the Synod of Chalcedon], Ph.D. Thesis, Aristotle University of Thessaloniki, 2009.

J.-N.M. Saint-Laurent, Apostolic Memories: Religious Differentiation and the Construction of Orthodoxy in Syriac Missionary Literature, Ph.D. thesis, Brown University, 2009.

I. Viezure, Verbum Crucis, Virtus Dei: A Study of Theopaschism from the Council of Chalcedon (451) to the Age of Justinian, Ph.D. thesis, University of Toronto, 2009.

J.E. Walters, The Philoxenian Gospels as Reconstructed from the Exegetical Writings of the Philoxenos of Mabbug, M.A. thesis, Abilene Christian University, Abilene 2009.

\section{Articles and chapters in collected volumes with extended treatment of Philoxenos}

P. Corssen, "Die Recension der Philoxeniana durch Thomas von Mabug," Zeitschrift für die Neutestamentliche Wissenschaft und Kunde der Älteren Kirche 2.1 (1901) 1-12.

W.E.A. Axon, "A Saying Attributed to Jesus By Philoxenos," Notes and Queries s9-IX, no. 226 (1902), 326.

A. Baumstark, "Die Evangelienexegese der syrischen Monophysiten," Oriens Christianus 2 (1902), 151-169, 358-389.

F. Nau, "Note inédite sur Philoxène, évêque de Maboug (485-519)," Revue de l'Orient chrétien I, 8:4 (1903), 630-633.

, “La naissance de Nestorius," Revue de l'Orient chrétien 14 (1909), 424-426.

J. Lebon, "La version philoxénienne de la Bible," Revue d'bistorie ecclésiastique 12 (1911), 413-436. 
A. Mingana, "New Documents on Philoxenos of Hierapolis, and on the Philoxenian Version of the Bible," The Expositor 8.19 [110] (1920), 149-160.

P. Peeters, "Comptes Rendu [Un nouveau document sur l'histoire des Turcs]," Byzantion 4 (1927-1928), 569-574. [Reprised in P. Peeters, Recherches d'Histoire et de Pbilosophie Orientales, vol. 1 (Brüssel 1951), 208-213.]

H. Guppy, "The Genuineness of 'Al-Tabari's Apology and of the Syriac Document on the Spread of Christianity in Central Asia in the John Rylands Library," Bulletin of the John Rylands Library 14.1 (1930), 121-124.

A. Mingana, "Remarks on the Early Spread of Christianity in Central Asia," Bulletin of the John Rylands University Library of Manchester 14 (1930), 123-124.

I. Hausherr, "Contemplation et sainteté: Une remarquable mise au point par Philoxène de Mabboug († 523)," Revue d'ascétique et de mystique 14 (1933), 171-195.

, "De doctrina spirituali Christianorum Orientalium. Quaestiones et scripta," Orientalia Christiana 30 (1933), 147-216.

, "Le 'De Oratione' d'Évagre le Pontique en syriaque et en arabe," Orientalia Christiana Periodica 5 (1939), 7-71.

A. Vööbus, "New Data for the Solution of the Problem Concerning the Philoxenian Version," in Spiritus et veritas. Festschrift Karl Kundzins (Eutin 1953), 169-186.

E. Bergsträsser, "Philoxenos von Mabbug: Zur Frage einer monophysitischen Soteriologie" in Gedenkschrift für D. Werner Elert (Berlin 1955), 43-61.

E. Lemoine, "Philoxène de Mabboug. Homélies sur la foi et sur la crainte de Dieu," La vie spirituelle 94 (1956), 252-261.

J. Gribomont, "Les Homélies ascétiques de Philoxène de Mabboug et l'écho du Messalianisme," L'Orient Syrien 2.1 (1957), 419-432.

I. Hausherr, "Spiritualité syrienne: Philoxène de Mabboug en version française," Orientalia Christiana Periodica 23.1 (1957), 171-85.

E. Lemoine, "La Spiritualité de Philoxène de Mabboug," L'Orient Syrien 2.1 (1957), 351-366.

T. Jansma, review of E. Lemoine, Pbiloxène de Mabbong. Homélies (1956), Vigiliae Christianae 12:4 (1958), 233-237.

E. Lemoine, "Physionomie d'un moine syrien: Philoxène de Mabboug," L'Orient Syrien 3.1 (1958), 91-102.

E. Beck, "Philoxenos und Ephräm," Oriens Christianus 46 (1962), 61-76. 
L. Abramowski, review of A. de Halleux, Philoxène de Mabbog. Sa vie, ses écrits, sa théologie, Revue d'histoire ecclésiastique 60 (1965), 859-866.

, "Ps.-Nestorius und Philoxenos von Mabbug," Zeitschrift für Kirchengeschichte 77 (1966), 122-125.

S.P. Brock, "Alphonse Mingana and the Letter of Philoxenos to Abu 'Afr," Bulletin of the John Rylands Library 50 (1967), 199-206.

J.-M. Fiey, "Auteur et date de la Chronique d'Arbelès" L'Orient Syrien 12 (1967) 265-302.

P. Harb, "Faut-il restituer à Joseph Hazzaya la Lettre sur les trois degres de la vie monastique attribuée à Philoxène de Mabboug?" Melto 4.2 (1968), 13-36.

, "L'attitude de Philoxène de Mabboug à l'égard de la spiritualité 'savante' d'Évagre le Pontique,' in F. Graffin, ed., Mémorial G. Khouri-Sarkis (1898-1968), fondateur et directeur de l'Orient syrien, 1956-1967 (Louvain 1969), 135-155.

"La Conception pneumatique chez Philoxène de Mabbūg," Meltho 5.1 (1969), 5-16.

, "Die Unechtheit des Philoxenos-Briefes über die drei Stufen des monastischen Lebens," in W. Voigt, ed., XVII. Deutscher Orientalistentag vom 21. bis 27. Juli 1968 in Würzburg: Vorträge, Zeitschrift der Deutschen Morgenländischen Gesellschaft, Supplement 1.2 (Wiesbaden 1969), 380-384.

P. Harb, "Le Rôle exercé par Philoxène de Mabbūg sur l'évolution de la morale dans l'église syrienne," Parole de l'Orient 1.1 (1970), 27-48.

P. Harb, "Les origines de la doctrine de la "la-hašušuta" (apatheia) chez Philoxène de Mabbug," Parole de l'Orient 5 (1974), 227-241.

T. Jansma, "Philoxenos' Letter to Abraham and Orestes Concerning Stephen Bar Sudaili: Some Proposals with Regard to the Correction of the Syriac Text and the English Translation," Le Muséon 87.1 (1974), 79-86.

A. Vööbus, "La Biographie de Philoxène: Tradition des manuscrits," Analecta Bollandiana 93 (1975), 111-114.

A. de Halleux, "A la source d'une biographie expurgée de Philoxène de Mabbog," Orientalia Lovaniensia Periodica 6-7 (1975-1976), 253266.

L. Wickham, review of R. Chesnut, Three Monophysite Christologies, Journal of Theological Studies 28 (1977), 576-571.

L. Abramowski, "Die Schrift Gregors des Lehrers "Ad Theopompum" und Philoxenos von Mabbug," Zeitschrift für Kirchengeschichte 89 (1978), 273-290 [English translation published as L. Abramow- 
ski, “Gregory the Teacher's 'Ad Theopompum' and Philoxenos of Mabbug," in L. Abramowski, Formula and Context: Studies in Early Christian Thought (Hampshire 1992), \#VIII [1-19].]

A. de Halleux, "Monophysitismus und Spiritualität nach dem Johanneskommentar des Philoxenos von Mabbug," Theologie und Philosophie 53:1 (1978), 353-366.

, "La Philoxénienne du symbole," in F. Graffin and A. Guillaumont, eds., Symposium Syriacum 1976 (Rome 1978), 295-315.

S.P. Brock, "Syriac Euthalian Material and the Philoxenian Version of the New-Testament," Zeitschrift fuir die Neutestamentliche Wissenschaft und die Kunde der alteren Kirche 70.1 (1979), 120-130.

A. Guillaumont, "La diffusion des opinions relatives à l'apocatastase chez Jacques de Saroug († 521) et Philoxène de Mabboug († 523)," Annuaire de l'École Pratique des Hautes Études, V' Section: Sciences Religieuses 88 (1979-80), 369-371.

F. Graffin, "Note sur l'exégèse de Philoxène de Mabboug à l'occasion du discours de S. Paul aux Athéniens (Actes 17, 31)," Parole de l'Orient 9 (1979-80), 105-111.

A. de Halleux, "Monophysitismus und Spiritualität nach dem Johanneskommentar des Philoxenos von Mabbog," in: W. Voigt, ed., XX. Deutscher Orientalistentag vom 3. bis 8. Oktober 1977 in Erlangen: Vorträge, Zeitschrift der Deutschen Morgenländischen Gesellschaft, Supplement 4 (Wiesbaden 1980), 66-67.

A. de Halleux, "Le Commentaire de Philoxène sur Matthieu et Luc: Deux éditions récentes," Le Muséon 93.1 (1980), 5-35.

C.N. Tsirpanlis, "Some Reflections on Philoxenos' Christology," Greek Orthodox Theological Review 25 (1980), 152-162.

J.W. Watt, "Philoxenos and the Old Syriac Version of Evagrius' Centuries," Oriens Christianus 64 (1980), 65-81.

B. Aland, "Die Philoxenianische-Harklensische Übersetzungstradition. Ergebnisse einer Untersuchng der neutestamentlichen Zitate in der syrischen Literatur," Le Muséon 94.3 (1981), 321-383.

S.P. Brock, "The Resolution of the Philoxenian/Harclean Problem," in E.J. Epp and G.D. Fee, eds., New Testament Textual Criticism. Its Significance for Exegesis. Essays in honor of Bruce M. Metziger (Oxford 1981), 325-343.

A. Grillmeier, "Die Taufe Christi und die Taufe der Christen. Zur Tauftheologie des Philoxenos von Mabbug und ihrer Bedeutung für die christliche Spiritualität," in H.J. auf der Maur et al., eds., 
Fides sacramenti sacramentum fidei. Studies in honour of Pieter Smulders (Assen 1981), 137-175.

B. Aland, "Monophysitismus und Schriftauslegung. Der Kommentar zum Matthäus und Lukasevangelium des Philoxenos von Mabbug," in P. von Hauptmann, ed., Unser ganzes Leben Christus unserm Gott überantworten. Studien zur ostkircblichen Spiritualität. Fairy von Lilienfeld zum 65. Geburtstag (Göttingen 1982), 142-66.

R.G. Jenkins, "Some Quotations from Isaiah in the Philoxenian Version," Abr-Nabrain 20 (1981-1982), 20-36.

A. Molina Prieto, "La Theotókos en las "Dissertationes" de Filoxeno de Mabbug," Marianum 44 (1982), 390-424.

J.W. Watt, “The Syriac Adapter of Evagrius' Centuries,” Studia Patristica 17 (1982), 1388-1395.

J. Martikainen, "Erkenntnistheorie bei Philoxenos von Mabbug," in F. Steppat, ed., XXI. Deutscher Orientalistentag vom 24. bis 29. März. 1980 in Berlin: Vorträge, Zeitschrift der Deutschen Morgenländischen Gesellschaft, Supplement 5 (Wiesbaden 1983), 133136.

A. de Halleux, “Le Mamlelã de 'Habbib' contre Aksenãyã. Aspects textuels d'une polémique christologique dans l'Église syriaque de la première génération post-chalcédonienne," in C. Laga, et al., eds., After Chalcedon: Studies in Theology and Church History Offered to Professor Albert Van Roey for His Seventieth Birthday, Orientalia Lovaniensia Analecta 18 (Leuven 1985), 67-82.

F. Graffin, "Quelques aspects de la doctrine monastique de Philoxène de Mabboug et sa Lettre à Patricius" in Association des amis de Sénanque, eds., Monachisme d'orient et d'occident: l'Orient monastique quelques jalons au cours du premier millénaire ([Sénanque, France] [1986]), 1-18.

M.A. Mathai, "The Concept of 'Becoming' in the Christology of Philoxenos of Mabbug," The Harp 2 (1989), 71-77.

R.G. Jenkins, "Quotations from Genesis and Exodus in the Writings of Philoxenos of Mabbug," Studia Patristica 18:4 (1990), 245-248.

J.W. Watt, "The Rhetorical Structure of the Memra of Eli of Qartamin on Philoxenos of Mabbug," in: R. Lavenant (ed.), V Symposium Syriacum, 1988: Katholieke Universiteit, Leuven, 29-31 août 1988 (Orientalia Christiana Analecta 236; Roma: Pontificium Institutum Studiorum Orientalium, 1990), 299-306.

M. Mar Severios [M.A. Mathai], "The Suffering, Death and Resurrection of Christ-A Philoxenian View," The Harp 4 (1991), 59-65. 
T. Baarda, "Philoxenos and the Parable of the Fisherman: Concerning the Diatessaron Text of Mt 13, 47-50," in F. van Segbroeck, et al. eds., The Four Gospels 1992: Festscbrift Frans Neirynck, vol. 2 (Leuven 1992), 1403-1423.

, '“He Holds the Fan in His Hand...' (Mt 3:12, Lk 3:17) and Philoxenos, or How to Reconstruct the Original Diatessaron Text of the Saying of John the Baptist?," Le Muséon 105.1 (1992), 63-86.

P.S. Cowe, "Philoxenos of Mabbug and the Synod of Manazkert," ARAM 5.1 (1993), 115-129.

Tjitze Baarda, "The Syriac Versions of the New Testament," in B.D. Herman and M.W. Holmes, eds., The Text of the New Testament in Contemporary Research. Essays on the Status Quaestionis (Grand Rapids, Mich 1995), 97-112.

M. Nin, "Progresso spirituale ad esperienza di Dio in alcuni testi monastici siriaci," in M. Starowieyski, ed., The Spirituality of Ancient Monasticism (Cracow 1995), 105-133.

V.-P. Seppälä, "Syrialaisen evankeliumitekstin historiasta," Ortodoksia 46 (1997), 18-33 [non vidi].

J. Hatem, "Le moine et l'un chez Philoxene de Mabboug," in Le monachisme syriaque aux premiers siècles de l'Eglise, II - debut VII' siècle. I: Textes français (Antélias, Liban 1998), 219-234.

J.P. Mathew, "Philoxenos of Mabbug. The Eighth Discourse on Poverty," The Harp 13 (2000), 173-176.

Robin Darling Young, "Philoxenos of Mabbugh and the Syrian Patristic Understanding of Justification," Communio 27 (2000), 688-700.

S.P. Brock, "Syriac into Greek at Mar Saba: The Translation of St. Isaac the Syrian," in J. Patrich, ed., The Sabaite heritage in the Orthodox Church from theFifth Century to the Present, Orientalia Lovaniensia Analecta 98 (Leuven 2001), 200-208.

L. Abramowski, "Aus dem Streit um das 'Unus ex trinitate passus est': Der Protest des Habib gegen die Epistula dogmatica des Philoxenos an die Mönche," in A. Grillmeier and T. Hainthaler, eds., Jesus der Christus im Glauben der Kirche: Die Kirchen von Jerusalem und Antiocbien nach 451 bis 600 (Freiburg 2002), 570-647.

T. Bou Mansour, "Die Christologie des Philoxenos von Mabbug," in A. Grillmeier and T. Hainthaler, eds., Jesus der Christus im Glauben der Kirche: Die Kirchen von Jerusalem und Antiocbien nach 451 bis 600 (Freiburg 2002), 500-569. 
Theresia Hainthaler, "Der persische Disputator Simeon von Beth Aršam und seine antinestorianische Positionsbestimmung," in A. Grillmeier and T. Hainthaler, eds., Jesus der Christus im Glauben der Kirche: Die Kirchen von Jerusalem und Antiochien nach 451 bis 600 (Freiburg 2002), 262-276.

P. Bruns, "Aristoteles-Rezeption und Entstehung einer syrischen Scholastik. Am Beispiel von Iunilius Africanus' Übersetzung der 'instituta regularia' des Paul von Nisibis, Philoxenos von Mabbug und Babai dem Grossen," in P. Bruns, ed., Von Athen nach Bagdad. Zur Rezeption griechischer Philosophie von der Spätantike bis zum Islam (Bonn 2003) 29-41 [non-vidi].

R. Kitchen, "Syriac Additions on Anderson: The Garden of Eden in the Book of Steps and Philoxenos of Mabbug," Hugoye 6.1 (2003).

R. Bondi, "Living by the Word: Monastic Mentors," Christian Century (Novemeber 2, 2004), 16.

A.I. Lehto, "Aphrahat and Philoxenos on Faith," Journal of the Canadian Society for Syriac Studies 4 (2004), 47-59.

L. Van Rompay, "Mallpânâ dilan Suryâyâ. Ephrem in the Works of Philoxenos of Mabbog: Respect and Distance," Hugoye 7.1 (2004), n.p.

A. Kofsky, and S. Ruzer, "Christology and Hermeneutics in Philoxenos' Commentary on John 1:14," Orientalia Cbristiana Periodica 71:2 (2005), 343-362.

G. Kourie, "The 'Theotokos' according to Philoxenos of Mabboug” [in Arabic] in Theological and Dogmatic Articles (Damascus 2006), 3-19 [non vidi].

G. Kourie, "Faith, Science, and Knowledge according to Philoxenos of Mabboug" [in Arabic] in Theological and Dogmatic Articles (Damascus 2006), 20-29 [non vidi].

W. van Peursen, "Sirach Quotations in the Discourses of Philoxenos of Mabbug: Text and Context," in: R.B. ter Haar Romeny (ed.), The Peshitta: Its Use in Literature and Liturgy. Papers Read at the Third Peshitta Symposium (Leiden 2006), 243-258.

K. Pinggéra, "Christi Seele und die Seelen der Gerechten. Zum fünften Fragment aus dem Johanneskommentar des Philoxenos von Mabbug," Studia Patristica 41 (2006), 65-70.

J.W. Watt, "Two Syriac Writers from the Reign of Anastasius: Philoxenos of Mabbug and Joshua the Stylite," The Harp 20 (2006), 275-293. 
G. Kourie, "Passions and purification according to Philoxenos of Mabboug" [in Arabic], Syrian Orthodox Patriarchal Journal 264-70 (2007), 210-230 [non vidi].

M. Nin, "La Lettera ai monaci di Senun di Filosseno di Mabbug: un esempio di cristologia anticalcedoniana in ambiente siriaco nel VI secolo," in E. Vergani and S. Chialà, eds., La tradizione cristiana Sirooccidentale (V-VII secolo). Atti del $4^{\circ}$ Incontro sull'Oriente Cristiano di tradizione siriaca (Milano, Biblioteca Ambrosiana, 13 maggio 2005) (Milano 2007), 83-108.

L. van Rompay, "Bardaisan and Mani in Philoxenos of Mabbog's Mèmrè against Habbib," in W.J. van Bekkum et al, eds., Syriac Polemics: Studies in Honour of Gerrit Jan Reinink, Orientalia Lovaniensia Analecta 170 (Leuven 2007), 77-90.

R.-Y. Akhrass, "La parole de Dieu dans la vie du moine selon Philoxène de Mabboug" (in Arabic) Awräk rubbäniyya 92-93 (2008), 241258.

, "La théologie de l'eucharistie chez Philoxène de Mabboug," Revue théologique de Kaslik 2 (2008), 57-71 [augmented Arabic version in Syrian Orthodox Patriarchal Journal 281-283 (2009), 4762], [non vidi].

P.A.L. Hill, "Matthew 16:18 in the Philoxenian Version," TC: A Journal of Biblical Textual Criticism 13 (2008), 1-17.

D.A. Michelson, "Though He Cannot Be Eaten, We Consume Him": Appeals to Liturgical Practice in the Christological Polemic of Philoxenos of Mabbug," in: G.A. Kiraz (ed.), Malphono w-Rabo d-Malphone: Studies in Honor of Sebastian P. Brock (Piscataway, NJ: Gorgias Press, 2008), 439-476.

G. Kourie, "The cause and aim of incarnation of God Logos according to Philoxenos of Mabboug" [in Arabic], Syrian Orthodox Patriarchal Journal 284-6 (2009), 180-191 [non vidi].

R.-Y. Akhrass, "La Vierge Mère de Dieu dans la pensée de Philoxène de Mabboug," Hugoye 13:1 (2010), 31-48.

D. King, "New Evidence on the Philoxenian Version of the New Testament and Nicene Creed," Hugoye 13:1 (2010), 9-30.

R.A. Kitchen, "Introduction," Hugoye 13:2 (2010), 3-6. . "The Lust of the Belly is the Beginning of All Sin: Practical Theology of Asceticism in the Discourses of Philoxenos of Mabbug," Hugoye 13:1 (2010), 49-63. review of Lemoine, E. and Lavenant, R., trans., Pbiloxène de Mabboug. Homélies (1956 and 2007), Hugoye 13:1 (2010), 65-73. 
A. McCollum, "An Arabic Scholion to Genesis 9:18-21 (Noah's Drunkenness) Attributed to Philoxenos of Mabbug," Hugoye 13:2 (2010), 7-30.

D.A. Michelson, "A Biblographic Clavis to the Works of Philoxenos of Mabbug," Hugoye 13:2 (2010), 154-219.

. "Introduction to the Double Issue on Philoxenos of Mabbug," Hugoye 13:1 (2010), 3-8.

D.M. Odorisio, “Thomas Merton's Novitiate Conferences on Philoxenos of Mabbug (April-June 1965): Philoxenos on the Foundations of the Spiritual Life and the Recovery of Simplicity" by Thomas Merton OCSO, introduced and transcribed by David M. Odorisio," Hugoye 13:2 (2010), 133-153.

I. Viezure, "Argumentative Strategies in Philoxenos of Mabbug's Correspondence: From the Syriac Model to the Greek Model," Hugoye 13:2 (2010), 31-57.

, "Philoxenos of Mabbug and the Controversies over the "Theopaschite Trisagion,"” in Studia Patristica XLVIII (2010): 137-146.

J.E. Walters, "The Philoxenian Gospels as Reconstructed from the Writings of Philoxenos of Mabbug," Hugoye 13:2 (2010), 59-131.

R.-Y. Akhrass, "Le sacerdoce dans la théologie de Philoxène de Mabboug," (in Arabic) Al-Manara 51/2 (forthcoming).

R. Darling Young, "The Influence of Evagrius of Pontus on the Early Monastic Thought of Philoxenos of Mabbug," in R. Darling Young and M. Blanchard, "To Dwell Beside the Enclosure of That Garden": Studies in Syrian Asceticism (Washington, D.C. forthcoming).

\section{E. Articles and chapters in collected volumes with mention of Philoxenos}

M.-A. Kugener, "Allocution prononcée par Sévère après son élévation sur le trône patriarcale d'Antioche," Oriens Christianus 2 (1902), 265-271.

F. Nau, "Notes sur diverses homélies pseudépigraphiques, sur les œuvres attribuées à Eusèbe d'Alexandrie et sur un nouveau manuscrit de la chaîne contra Severianos," Revue de l'Orient chrétien 2.3 [13] (1908), 406-435.

M. Sprengling. "Antonius Rhetor on Versification with an Introduction and Two Appendices," The American Journal of Semitic Languages and Literatures 32.3 (1916), 145-216. 
A. Jülicher, "Zur Geschichte der Monophysitenkirche," Zeitschrift für die Neutestamentliche Wissenschaft und die Kunde der Älteren Kirche 24.1 (1925), 17-43.

R.H. Connolly, "A Negative Form of the Golden Rule in the Diatessaron?," Journal of Theological Studies OS 35 [140] (1934), 351-357.

M. Jugie, "La primauté romaine d'aprés les premiers théologiens monophysites," Échos d'Orient 33 (1934), 181-189.

H.-G. Opitz, "Das syrische Corpus Athanasium," Zeitschrift fir die Neutestamentliche Wissenschaft und Kunde der Älteren Kirche 33 (1934), $18-31$.

R.H. Connolly, "A Negative Form of the Golden Rule in the Syriac Acts of Thomas?," Journal of Theological Studies OS 36 [140] (1935), 353-356.

I. Hausherr, "Les grands courants de la spiritualité orientale," Orientalia Christiana Periodica 1 (1935), 114-138.

- "Aux origines de la mystique syrienne: Gregoire de Chypre ou Jean de Lycopolis?" Oxford Classical and Pbilosophical Monographs 4 (1938), 497-520.

A. Grillmeier and H. Bacht, eds., Das Konzil von Chalkedon: Geschichte und Gegenwart, 3 vols. (Frankfurt am Main 1951-1954).

I. Hausherr, "Ignorance infinie ou science infinie?," Orientalia Christiana Periodica 25 (1959), 44-52.

T. Jansma, "The Credo of Jacob of Serūgh: A Return to Nicaea and Constantinople," Nederlands Archief voor Kerkgeschiedenis 44 (1960), $18-36$.

L. Wickham, review of W.H.C. Frend, The Rise of the Monophysite Movement, Journal of Theological Studies 24 (1973), 591-599.

K. Ware, review of W.H.C. Frend, The Rise of the Monophysite Movement, English Historical Review 91.395 (1976), 354-356.

S.P. Brock, "Iconoclasm and the Monophysites," in A. Bryer and J. Herrin, eds., Iconoclasm: Papers Given at the Ninth Spring Symposium of Byzantine Studies, University of Birmingham, March 1975 (Birmingham 1977), 53-57.

, "Limitations of Syriac in Representing Greek" in B. Metzger, ed., The Early Versions of the New Testament: Their Origin, Transmission, and Limitations (Oxford 1977), 83-98.

A. Vööbus, "Discovery of a Treatise about the Ecclesiastical Administration Ascribed to Michael the Syrian: A Unique 
Document in the Literary Genre of Canon Law," Church History 47.1 (1978), 23-26.

A. de Halleux, "Le Christologie de Jean le Solitaire," Muséon 94.3-4 (1981), 5-36.

S.P. Brock, "From Antagonism to Assimilation: Syriac Attitudes to Greek Learning," in N. Garsoïan, ed., East of Byzantium: Syria and Armenia in the Formative Period (Washington 1982), 17-34; reprinted in S.P. Brock, Syriac Perspectives on Late Antiquity (London 1984), ch. V.

, "Passover, Annunciation and Epiclesis - Some Remarks on the Term Aggen in the Syriac Versions of Luke 1.35," Novum Testamentum 24.3 (1982), 222-233; reprinted in S.P. Brock, Fire from Heaven: Studies in Syriac Theology and Liturgy, (Aldershot, 2006), ch. XII.

A. de Halleux, "Die Genealogie des Nestorianismus nach der frühmonophysitischen Theologie," Oriens Christianus 66 (1982), 1-14.

J.C. McCullough, "Early Syriac Commentaries on the New Testament," Near East School of Theology Theological Review 5 (1982), 14-33, 79126.

S.P. Brock, "Towards a History of Syriac Translation Technique," Orientalia Christiana Analecta 221 (1983), 1-14; reprinted in S.P. Brock, Studies in Syriac Christianity (Aldershot 1992), ch. X. , "Hebrews 2:9B in Syriac Tradition," Novum Testamentum 27:3 (1985), 236-244.

J.S. Siker, "The Canonical Status of the Catholic Epistles in the Syriac New Testament," Journal of Theological Studies 38.2 (1987), 311 340.

S. Brock, "Maggnanuta: A Technical Term in East Syrian Spirituality and Its Background," in R.G. Coquin et al., eds., Mélanges Antoine Guillaumont (Geneva 1988), 121-129.

, "From Annunciation to Pentecost: The Travels of a Technical Term," in S. Parenti, and E. Carr, eds., Eulogema: Studies in Honor of Robert Taft S.J., Studia Anselmiana (Rome 1993), 71-91; reprinted in S.P. Brock, Fire from Heaven: Studies in Syriac Theology and Liturgy, (Aldershot, 2006), ch. XIII.

W. Witakowski, "Syrian Monophysite Propaganda in the Fifth to Seventh Centuries," in L. Rydén and J.O. Rosenqvist, eds., Aspects of late Antiquity and early Byzantium 4: Papers read at a Colloquium beld at the SRII 31 May - 5 June 1992 (Stockholm 1993), 57-66. 
S.P. Brock, review of J. Martikainen, Johannes I. Sedra, Journal of Theological Studies n.s. 45 (1994), 364-368.

S.H. Griffith, "Julian Saba, 'Father of the Monks' of Syria," Journal of Early Christian Studies, 2.2 (1994), 185-216.

S.P. Brock, "Notulae syriacae: Some Miscellaneous Identifications," Le Muséon 108:1-2 (1995), 69-78.

B. Daley, 'What Did 'Origenism' Mean in the Sixth Century?” In G. Dorival and A. le Boulleuc, eds., Origeniana Sexta: Origen and the Bible (Leuven 1995), 627-638.

S.P. Brock, "The Gates/Bars of Sheol Revisited," in W.L. Petersen et al., eds., Sayings of Jesus_Canonical and Non-canonical: Essays in Honour of Tjitze Baarda (Leiden 1997), 7-24.

, "The Transmission of Ephrem's Madrashe in the Syriac Liturgical Tradition," Studia Patristica 33 (1997), 490-505.

T. Bohm, "Remarks on Syriac translations of the 'Prologue of John'," Zeitschrift Fur Die Neutestamentliche Wissenschaft Und Die Kunde Der Alteren Kirche 89.1 (1998), 45-65.

A.M. Saadi, "Christological Contention and Tolerance in the Syriac Church Traditions," Journal of Assyrian Academic Studies 12.1 (1998), 47-57.

S.P. Brock, "Towards a Typology of the Epicleses in the West Syrian Anaphoras," in H.-J. Feulner, et al., eds., Crossroad of Cultures. Studies in Liturgy and Patristics in Honor of Gabriele Winkler, Orientalia Christiana Analecta (Rome 2000), 173-192; reprinted in S.P. Brock, Fire from Heaven: Studies in Syriac Theology and Liturgy, (Aldershot, 2006), ch. VIII.

P. Gray, "The Sabaite Monasteries and the Christological Controversies (478-533)," in J. Patrich, ed., The Sabaite heritage in the Orthodox Church from theFifth Century to the Present, Orientalia Lovaniensia Analecta 98 (Leuven 2001), 237-244.

J.N. Ford, "Two Syriac Terms Relating to Ophthalmology and their Cognates," Journal of Semitic Studies 47.1 (2002), 23-38.

S.J. Beggiani, "The typological approach of Syriac sacramental theology," Theological Studies 64.3 (2003), 543-557.

V. Menze, "Die Stimme von Maiuma. Johannes Rufus, das Konzil von Chalkedon und die wahre Kirche," in J. Hahn and C. Ronning, eds., Literarische Konstituierung von Identifikationsfiguren in der Antike (Tübingen 2003), 215-32.

S.P. Cowe, "Armenian Christology in the seventh and eighth centuries with particular reference to the contributions of Catholicos 
Yovhan Ōjnec'I and Xosrovik T'Argmanič'," Journal of Theological Studies 55.1 (2004), 1-54.

V. Menze, "Priest, Laity and the Sacrament of the Eucharist in Sixth Century Syria," Hugoye 7.2 (2004), n.p.

L. Van Rompay, "Society and Community in the Christian East," in M. Maas, ed., The Cambridge Companion to the Age of Justinian (Cambridge 2005), 239-266.

B. Caseau, "Sancta sanctis: Normes et gestes de la communion entre Antiquité et haut Moyen Age," in Pratiques de l'eucharistie dans les Eglises d'Orient et d'Occident (Antiquité et Moyen Age), I: L'institution. Actes du séminaire tenu à Paris, Institut catholique (1997-2004), N. Bériou et al., eds. (Paris 2009), 371-420.

S. Plathottathil, "Christological Differences between East and West Syrian Traditions,"'The Harp 24 (2009), 285-309. 